\title{
Residential Private Governments: An Introductory Survey*
}

\author{
Uriel Reichman $\dagger$
}

Today many home buyers, on the purchase of an apartment in a condominium or cooperative or a house in a small subdivision or large-scale new community, become automatically subject to the authority of some type of homeowners' association. ${ }^{1}$ Although based on a mix of private law concepts of contract and property, such associations are generally organized in a manner similar to the public law model of municipal government. ${ }^{2}$ All homeowners are bound, usually by encumbrances on their property, to abide by the dictates of the association, which is empowered to create, alter and enforce a comprehensive set of regulations governing important aspects of community life. Because homeowners' associations possess much of the power and trappings of local municipal government but arise out of private relationships, they will be described as "residential private governments."3

The development of residential private governments has to some extent outpaced the development of the legal standards necessary to deal with them. My intention in this paper is to begin analysis of the residential private government phenomenon and eventually to suggest a legal framework to guide future regulation. The

* This article is excerpted from the author's doctoral thesis submitted to The University of Chicago Law School. The author would like to thank Professors Allison Dunham, Richard Epstein, Stanley Katz and Max Rheinstein of The University of Chicago Law School and Professor Owen Fiss of Yale Law School. The author's gratitude is likewise extended to Mr. Albert Foer of the District of Columbia Bar and to the developers of the communities mentioned in note 59 infra for providing valuable information.

$\dagger$ Lecturer, Tel-Aviv University Law School.

' Homeowners' associations generally involve dwelling units that are owned by their inhabitants; they may, however, also exist among leaseholders, most notably in mobile home parks.

${ }^{2}$ See, e.g., Ascher, Private Covenants in Urban Redevelopment, in Urban Development Problems and Practices 223, 282 (C. Woodbury ed. 1953).

3 The term "residential private government" has been used before in the legal literature describing the phenomenon of the homeowners' association. See Comment, Democracy in the New Towns: The Limits of Private Government, 36 U. CHI. L. Rev. 379 (1969) [hereinafter cited as Chicago Comment]. In fact, it was suggested by the community developers themselves; see the testimony of James W. Rouse, the developer of Columbia, Maryland, Hearings on H.R. 12341, H.R. 12946, H.R. 13064, H.R. 9256 Before the Subcomm. on Housing of the House Comm. on Banking and Currency, 89th Cong., 2d Sess.,. pt. 2, at 1054 (1966). 
paper thus begins by examining the nature and growth of the residential private government movement and then seeks to describe the relations among the participants in that movement within the context of community aspirations and individual property rights. With this background, the third section goes on to set forth a policy rationale for preferring a private, rather than a public, law construct for resolving disputes between the residential private government and individual homeowners. An examination of the conflicts that may arise between developers and residents follows, along with a possible framework for achieving a principled resolution of those conflicts. Finally, the last section broadens the scope of the investigation and elaborates on the arguments of some commentators that the movement has or will have an adverse impact on the public interest.

Throughout the paper, federally sponsored new towns will be referred to as convenient examples of the problems and possible solutions associated with residential private governments. Although they are aided and, to some extent, controlled by the federal government and are generally larger than most privately developed communities, new towns have similar organizational structures and are subject to many of the same economic pressures as residential private governments.

\section{The Residential Private Government Phenomenon}

When an individual takes up residence in a city, he automatically establishes a set of complex legal relations with the local municipal government: he is subjected to a comprehensive set of rules, granted a variety of rights, and is entitled to participate in the local political process. In the same way, by the simple act of acquiring title, a home buyer entering a community regulated by a residential private government automatically becomes the "subject" of the organization, owes various legal obligations, and is entitled to specific benefits.

The similarity between the residential private government and its public counterpart also extends to structural matters. The private government is organized on the basis of certain notions of democratic participation. The "government" is run by elected officials, each homeowner has the right to vote, and the majority has the power to change the community's norms. A division between "administrative" and "legislative" branches is often maintained. While certain matters are determined by the discretionary judgment of the organization's directors and agencies, the basic rules can be abolished or amended only by the homeowners' general assembly. More- 
over, in contrast to traditional methods of private planning, which use "regular" servitudes in an attempt to bind property owners permanently to particular types of conduct, the possibility of change in a homeowners' association is always present. A home buyer cannot possibly know in advance what regulations he will face in the future. After he moves in, he may find that large sections of the "local law" have been replaced. If he is dissatisfied with the change, the only remedy currently available, apart from seeking "political" change, is to sell the property and leave the community - the same last recourse that a citizen subject to a public municipal government has under similar circumstances.

Finally, there is a resemblance between the regulatory provisions maintained by both the public and private systems. Horizontal housing developments impose semi-zoning restrictions, maintain a system of private taxation (usually based on the unit's assessed value), employ building and business permit control devices, and supervise potential nuisance-producing activities. Comprehensive services like those usually supplied by municipalities may be furnished by the private organization: parks, recreational and cultural facilities may be provided along with the more traditional services such as street maintenance, snow removal, and garbage collection. Vertical developments have different problems and accordingly impose somewhat different rules and provide different services. All of this regulation, in both horizontal and vertical developments, has not, however, met with much protest or even recognition by home buyers; people have simply become accustomed to being handed, along with their deeds, booklets containing an elaborate set of rules that not only will affect their behavior within their own quarters and in common areas but may subject them to unforeseeable liabilities and even punitive measures as well.

While the "governmental" features of homeowners' associations cannot be denied, ${ }^{4}$ these entities are, nevertheless, of a "private" nature. The structure of legal relations within the association is generally imposed by land developers who do not receive governmental financial aid. The legal devices employed to bind homeowners to the observance of the necessary rules are private law devices.

- Organizations of landowners or leaseholders that possess these governmental characteristics are not limited to residential developments. In shopping centers where the leases require renters to join commercial associations and in business condominiums, for example, similar organizations exist to guarantee certain controls and the provision of services. On shopping center organizations, see generally Note, The Antitrust Implications of Restrictive Covenants in Shopping Center Leases, 86 HARv. L. REv. 1201 (1973); as to business condominiums, see D. Clurman, The Business Condominium (1973). These types of arrangements are outside the scope of the present work. 
In fact, the entire phenomenon of homeowners' associations is based on private initiative, private money, private property and private law concepts. While public government supervision is evident to a minimal extent, ${ }^{5}$ and might increase in the future, the homeowners' association movement was neither created nor implemented by public agencies. ${ }^{6}$

\section{A. The Growth of the Residential Private Government Movement}

Found in the cities, suburbs and new towns, in recreational, retirement and regular residential communities, residential private governments have multiplied greatly over the past decade. Sixtyeight percent of the cooperative and condominium units in larger structures (50 dwelling units or more) which were part of the housing supply in 1970 were built between 1960 and 1970; about 56 percent of the units in smaller projects (2-49 units per structure) were built during the same period. ${ }^{7}$ From 1970 to 1974 condominium ownership rose five-fold, from 416,000 units to approximately 2,000,000 units. The Department of Housing and Urban Development has predicted that one-half of the United States population will be living in condominiums within the next twenty years. ${ }^{8}$ In 1962 there were probably fewer than 500 associations in the United States to which a homeowner would automatically belong upon acquisition of title; by early 1973 the estimated number of such associations was 15,000 . Based on housing starts, the best estimate is that such organizations will continue to be created at the rate of approximately 4,000 each year. ${ }^{9}$

Despite this apparently widespread change in community relationships, the recent trend toward residential private governments has been largely ignored by scholars. Community sociologists who devoted much attention in recent years to the new town movement have overlooked the social impact of participation in residential

5 Government supervision, however, has generally been confined to condominiums. See A. FERRER \& K. STECHER, LAW OF CONDOMINIUM (1967) (compendium of state statutes regarding condominiums); Symposium on the Law of Condominiums, 48 ST. JohN's L. Rev. 9331010 (1974).

- Some developments were, and are, controlled by government entities (e.g., the Atomic Energy project and public housing run by public landlords), but as such they are beyond the scope of this paper.

'U.S. Bureau of the Census, Dep't of Commerce, Cooperative and Condominium Housing, Table A-6 (1973).

- Proxmire, Introduction to the Symposium on the Law of Condominiums, 48 ST. JoHN's L. REv. xi (1974).

- Urban land Inst. \& Community Ass'n Inst., Managing a Successful Community Association 2 (J. Goldberg ed. 1974). This data probably also includes condominiums that have residential private governments. 
private governments. And, while legal scholars have discussed particular problems relating to housing under public or private residential governments separately, they have never comprehensively analyzed the more general issue of life under a residential private government.

The failure of scholars to focus specifically on this area may have several explanations. First, the homeowners' association is by no means a new invention. The idea of a group of urban homeowners collectively possessing an exclusive right to use a park and contributing towards its maintenance was used in England as early as 1743. ${ }^{10}$ The first recorded homeowners' association in the United States was founded in Boston in 1844. ${ }^{11}$ Prototypes of modern residential private governments emerged in a modest form at the turn of the century. Starting with Roland Park, Baltimore in $1891,{ }^{12}$ and followed by several other well-known developments, ${ }^{13}$ the new system rapidly became well established. In 1938 the New York Court of Appeals gave its unequivocal endorsement to the homeowners' association, ${ }^{14}$ and other courts soon followed suit. ${ }^{15}$ Easy acceptance

10 This arrangement was used in Leicester Square, the subject of the famous controversy in Tulk v. Moxhay, 41 Eng. Rep. 1143 (Ch. 1848). A similar arrangement was first employed in the United States in Manhattan's Gramercy Park in 1831. Ascher, supra note 2, at 229. The legal device used there, and later in numerous similar situations, was a trust in which title to the park was vested in trustees for the benefit of the surrounding lands. Another approach used to accomplish the same end was based on lease arrangements. Title to the entire development was held by either an organization, trustees or the developer. The home buyers were granted long-term leases that included rights to enjoy the open space maintained by the "landlord" and financed by "rents" exclusively designated for that purpose. Such arrangements were used in America from at least 1870. Urban Land INST., Tech. Bull. No. 50, The Homes Association HandBook 39, 113 (1964) [hereinafter cited as The Homes AssoCIATTON HANDBOOK]. A third method of providing communal benefits to a certain group of homeowners was through the organization of a homeowners' association.

"The Homes Association Handbook 39.

${ }^{12}$ Id.

13 These developments included Kensington, New York (1909), St. Francis Wood, San Francisco (1912), Forest Hills Gardens, New York (1913) and Mission Hills, Kansas City (1914). For a description of these early homeowners' associations, see The HoMes Association HaNDBOoK 39-54, 110-13. See also Ascher's discussion of the Radburn, New Jersey, experience (1929) under a scheme of organization resembling the modern residential private government. Ascher, supra note 2, at 278-309.

14 Neponsit Property Owners' Ass'n v. Emigrant Indus. Sav. Bank, 278 N.Y. 248, 15 N.E.2d 793 (1938).

is Cases following Neponsit upholding the standing of homeowners' associations to enforce and protect the rights of their members include: Adaman Mut. Water Co. v. United States, 278 F.2d 842 (9th Cir. 1960); Merrionette Manor Homes Improvement Ass'n v. Heda, 11 III. App. 2d 186, 136 N.E.2d 556 (1956); Garden Dist. Property Owners Ass'n v. City of New Orleans, 98 So. 2d 922 (La. Ct. App. 1957); Zamiarski v. Kozial, 18 App. Div. 2d 297, 239 N.Y.S.2d 221 (1963); Carman v. Hewitt, 280 App. Div. 866, 105 N.Y.S.2d 239 (Sup. Ct. 1951), aff'd, 305 N.Y. 718, 112 N.E.2d 785 (1953).

Cases following the Neponsit analysis and allowing assessment obligations to "run with 
of this arrangement may thus have an historical explanation: voluntary associations are indeed, as de Tocqueville noted over a century ago, a common American phenomenon, ${ }^{16}$ and from early times servitudes have been imposed on property for the purpose of facilitating common ventures.

Another explanation for the lack of scholarly interest in the residential private government phenomenon is its apparently nonrevolutionary nature: these organizations are not initiated by a group of individuals seeking new community relations; rather they are "custom-made" legal structures supplied by developers along with the physical structures. Accordingly, the sudden popularity of the homeowners' association does not indicate, on its face, any social change. The entrepreneurs responsible for creating such associations probably had nothing further from their minds than a desire to experiment with new and innovative social planning. ${ }^{17}$ What they were interested in, instead, was meeting the desires of their customers for a better physical, rather than social, environment. Thus it was the market place that molded the community structure to accommodate both consumer demands and entrepreneurial interests.

The sixties marked a noticeable change in the building industry as capital-rich corporations became increasingly involved in the real estate market. Land development became big business and major corporations entered the field for the first time. Appreciating the profit potential involved, ${ }^{18}$ traditional money suppliers to builders,

the land," an essential prerequisite to the establishment of a homeowners' association, include: 165 Broadway Bldg., Inc. v. City Investing Co., 120 F.2d 813 (2d Cir. 1941); United States v. Aho, 68 F. Supp. 358 (D. Ore. 1944); Henlopen Acres, Inc. v. Potter, 36 Del. Ch. 141, 127 A.2d 476 (1956); Phillips v. Smith, 240 Iowa 863, 38 N.W.2d 87 (1947); Burton Jones Dev., Inc. v. Flake, 368 Mich. 122, 117 N.W.2d 110 (1962); Mendrop v. Harrell, 233 Miss. 679, 103 So. 2d 418 (1958); Petersen v. Beekmere, Inc., 117 N.J. Super. 155, 283 A.2d 911 (1971); University Gardens Property Owners Ass'n v. University Gardens Corp., 88 N.Y.S.2d 734 (Sup. Ct. 1948); Harrison-Rye Realty Corp. v. New Rochelle Trust Co., 177 Misc. 776, 31 N.Y.S.2d 1005 (Sup. Ct. 1941); Hughes v. City of Cincinnati, 175 Ohio St. 381, 195 N.E.2d 552 (1964); Peto v. Korach, 17 Ohio App. 2d 20, 244 N.E.2d 502 (1969); Rodruck v. Sand Point Maintenance Comm'n, 48 Wash. 2d 565, 295 P.2d 714 (1956).

" "Wherever, at the head of some new undertaking, you see the government in France, or a man of rank in England, in the United States you will be sure to find an association." A. DE Tocquevilie, Democracy in America 319 (Oxford U. Press ed. 1948).

${ }^{17}$ It should be noted, however, that the new towns discussed in text and notes at notes 39-56 infra are exceptions.

is It was not until the late 1960 s that financial institutions realized that the profitability of real estate ventures should not be measured by pre-tax cash flow on total invested capital but rather according to the rate of return on the investment. According to the first standard, the performance of land developers was not very impressive (in 1970-71 between 8 and 15 percent in pre-tax profits); according to the second, however, it was substantially higher than the return on equity commanded by industrial corporations (20-40 percent profits were not 
such as insurance corporations and pension funds, made huge investments and employed more aggressive policies in order to acquire a "piece of the action." 19 Other large enterprises, not previously engaged in building and land development activities, likewise became involved in the land development market through a wave of mergers and acquisitions, ${ }^{20}$ through large-scale joint ventures, ${ }^{21}$ and through the formation of land development subsidiaries. ${ }^{22}$ At the same time, a growing number of building corporations went public and thus were able to tap the stock market for equity capital. ${ }^{23}$ The potential of the real estate market encouraged the construction of large-scale projects which, it was found, did not entail the difficulties that had traditionally hampered developers. ${ }^{24}$

Several recent changes in consumer behavior should also be noted. The relative prosperity of the last decade, together with the easy availability of mortgage money, brought about an increase in home ownership, as opposed to home rental. ${ }^{25}$ The sellers' market of the period following World War II, in which production could not meet demand, gave way to intensified sales competition among home builders. The individual buyer could afford to be more selective, and thus new tastes, especially for certain luxuries, were developed. These consumer preferences became so important that, as a 1964 study indicated, the presence or lack of certain facilities often determined the success or failure of a development. ${ }^{26}$

These trends towards intensified competition in the building industry and increased sophistication in consumer preferences complemented and reinforced each other to such an extent that swimming pools, golf courses, parks, private beaches, tennis courts, and the like have become fixtures in even relatively inexpensive horizontal and vertical developments. New types of housing developments

uncommon). The reason for this difference is the superior leverage (borrowing power) inherent in the real estate business. See L. Goodkin, When Real Estate and Home Building Becomes Big Business 4-5 (1974).

" See Rose, The Future Largest Landlords in America, Fortune, July 1970, at 90.

20 See L. Grebler, Large Scale Housing and Real Estate Firms 8-9 (Table 1.3), 167-72 (notes) (1973).

2 See L. Goodkin, supra note 18, at 445-588.

22 See L. Grebler, supra note 20, at 14-15 (Table 1.5), 173-77 (notes).

${ }^{23}$ Id. at 6 (Table 1.2). Between 1963 and 1972 the number of public companies principally involved in building increased from seventeen to forty-one.

2 See generally id., ch. 3.

${ }^{25}$ Ownership rates rose from 46 percent in 1940 to about 62 percent in 1970 . It has been maintained that the increase was caused by four factors: a steady rise in income, the impact of government mortgage programs, a rise in marginal tax rates for middle income families, and the suburbanization of the large cities. See G. Carliner, Determinants of Home OwNERShIP (Inst. for Research on Poverty, U. of Wis. 1973).

26 The Homes Association HandBook, supra note 10, at 142. 
were created to satisfy consumers' demands for community facilities and common areas without prohibitive cost increases. Thus, for example, relatively inexpensive multifamily structures have been built in suburban subdivisions, ${ }^{27}$ a type of development traditionally dedicated to the single family home.

\section{B. Factors Influencing the Nature of the Private Residential Government}

The nature of modern housing developments has virtually dictated the establishment of residential private governments. Commonly-owned facilities need management, on-going financing and permanent regulation. Without them, such projects could easily fall into decay. Furthermore, the character of the new developments required the provision of certain services (such as complex indoor services in a multi-unit apartment house) that local governments furnish inadequately, if at all. The developer who intends to sell, rather than lease, the residential units will typically be interested in terminating his ties with the project as soon as possible in order to avoid tying up his resources on a completed project, collecting recurrent assessments, setting a permissible margin of profits, and satisfying the community's demands for service. The soundest and easiest way for the developer to solve managerial problems is to charge the owners themselves with the responsibility and let them operate as a nonprofit association to reduce costs. The structure of such an arrangement, however, must be formulated early enough to assure the first purchasers that the operation will be run efficiently and without serious friction after the developer turns over control. ${ }^{28}$

Yet the residential private government is structured in a way that serves the developer's more immediate interests as well. Several years are usually required to complete a project of, say, a few hundred units. During that time, stringent controls must be imposed on the independent builders working on individual lots and on the new residents of the emerging community to prevent them from damaging the rest of the project. To attract potential home

${ }^{27}$ A recent study confirmed the view that many people prefer a condominium or a townhouse apartment over a single family home because it provides them with freedom from house and yard maintenance. C. NoRCRoss, Townhouses \& CoNDOMINIUMS: RESIDENTS' LikES \& DisLikes 15 (1973). The interest in community facilities has influenced the growth of new public regulatory schemes of land use, such as Planned Unit Developments (PUDs). See, e.g., ALI Model Land Development Code \& 2-210 and commentary (Proposed Off. Draft 1975).

${ }^{28}$ Similar perceptions evidently underlie the requirement imposed by the Colorado Planned Unit Development Act, Colo. Rev. STat. ANn. § 106-6-7(6) (Cum. Supp. 1972), that PUD developers establish a homeowners' association before beginning construction on the project. 
buyers, various recreational facilities, designed to serve the entire community, are completed along with the first residential structures. To ensure that at least part of the operating costs of these facilities are covered, the infant private government scheme must allow the developer to levy assessments on the project's first residents. Even though the developer naturally fears interference with his long-range plan, the arrangements cannot be made too onesided: total domination by the developer could cause serious friction that might be costly in terms of litigation, work postponement and adverse publicity. Thus the system must allow the residents of the development to participate to a certain extent in the decisionmaking process by providing a mechanism for representation through which dissent may be expressed and compromises reached. Finally, the developer must also build into the private government scheme enough flexibility to enable him to modify plans and standards to meet unforeseen contingencies.

The structure of modern residential private governments was developed in response to the specific problems outlined above. The underlying bases for this new phenomenon, however, were the changing patterns of building industry competition and consumer tastes. But even though the residential private government was the product of thoroughly conventional shifts toward big business and more refined tastes, it may, in spite of itself, produce some new and unconventional results in human interaction.

\section{The Individual Homeowner and His Peers}

Thus far, I have sketched the rapid growth of the residential private government movement and the factors that both produced and shaped that growth. In this section, the implications of the residential private government movement for both the community and the individual homeowner will be explored. Thus the first part of the section briefly surveys the advantages that might accrue to people living in residential private government communities and the so-called new towns. The second part examines the price of those advantages, in terms of the erosion of basic concepts of personal liberty protected under and defined in terms of property rights.

\section{A. Advantages of Private Residential Government Communities}

Critics have often argued that American cities exemplify a cultural antithesis to community relations; it is said that, instead of encouraging the growth of community feeling and cooperation, the 
cities encourage isolation and the pursuit of individualistic ends. ${ }^{29}$ Research into this phenomenon has shown that the resultant alienation is a cause of mental disorder ${ }^{30}$ apathy to public affairs, and crime. ${ }^{31}$ This is not the place to examine the history of the decline of American community life. ${ }^{32}$ The results, in any event, are clear: the disappearance of the small community as a unit of production and consumption, the substitution of national for local community standards, and increased complexity at every level of society-often leading to impersonalization, inflexibility, and a reduction in local policy-making initiative.

At about the same time that the residential private government movement began to gain acceptance, several attempts were made to improve community life in the United States. ${ }^{33}$ The establishment of neighborhood control organizations was intended to produce decentralization, to reestablish locally controlled governments, to restore participatory democracy, and to implement the black power movement. On the federal level, programs such as model cities, new towns, and revenue-sharing were also geared towards societal decentralization and the reconstruction of community life. Some of the causes of the "youth revolt" of the sixties, exemplified by the call for direct democratic participation and experiments in new group identity, ${ }^{34}$ also appear to have been directed towards resurrecting the lifestyle that was lost as America became a more urban, industrialized nation.

Could the homeowners' association, which was intended to sail on the waters of conformity, bring about social change? Although

29 Already by the time of the Revolution privatism had become the American tradition. Its essence lay in its concentration upon the individual and the individual's search for wealth. Psychologically, privatism meant that the individual should seek happiness in personal independence and in search for wealth; socially, privatism meant that the individual should see his first loyalty as his immediate family, and that a community should be a union of such money making, accumulating families; politically, privatism meant that the community should keep the peace among individual money makers, and, if possible, help to create an open and thriving setting where each citizen would have some substantial opportunity to prosper.

S. Warner, The Private City 3 (1968).

so Levy \& Visotsky, The Quality of Urban Life: An Analysis from the Perspective of Mental Health, in Urban America: Goals \& Problems 100-08 (Subcomm. on Urban Affairs of the Joint Econ. Comm., 90th Cong., 1st Sess., 1967).

31 See T. Sellin, Culture Conflict and Crime, Soc. Science Res. Council, Bull. No. 41 (1938).

32 For one version of this process, see $R$. WARREN, The Community in America 53-94 (2d ed. 1972).

${ }^{33}$ See id. at 354-60 (evaluation of federal programs) and, generally, responses to the "great change in community life." Id. at 441.

${ }^{3}$ For an account of modern communal movements, see R. KANTER, CoMmITMENT AND Community (1972). 
the entrepreneurs who created them certainly did not intend to produce such a result, the structure of the homeowners' association could unwittingly provide a mechanism for reversing the anticommunity trends of the last century. Although the days of selfsufficient units are long over, community organization centered around the home, largely independent of general productionconsumption lines, still seems feasible. The homeowners' association, focusing on the total residential environment rather than nationwide interests, could provide a vehicle for this type of development. Residents may be expected to participate in the regular and extraordinary meetings of the residential private government out of basic self-interest: the decisions reached in each association meeting may affect each individual owner financially as well as by determining the standard of services to be supplied and the rules of behavior to be enforced. Since the compactness of the community makes each vote count, participatory democracy might be reinvigorated. Moreover, because the community will probably lack cultural homogeneity, community meetings may become a forum for debate where different views are aired, compromises reached, and decisions made by majority vote. The limited number of members and the custom of having the elected directors serve without pay might stimulate a system of rotation of community leadership and shared responsibility. The limited size of the developments ${ }^{35}$ might ensure that outside politics played only a limited role in the community's internal affairs. These elements, together with the sharing of common facilities, might encourage acquaintances and improve neighborhood relations. Finally, conducting their own affairs, rather than being the passive clients of business enterprises or government, could encourage the homeowners to develop self-reliance and to increase participation, thus strengthening their sense of identification with the community.

Having said all this, a few words of caution must be interjected. First, the movement toward residential private governments is not likely to reach the people who might benefit from it the most: the indigent and alienated segments of the population. Second, the hypothesis that innovative legal arrangements can improve social rela-

${ }^{33}$ It should be noted that some large-scale new developments are organized in several small "villages" with a separate homeowners' organization in each to eliminate the problem of overly large memberships. For expressions of dissatisfaction with large projects, see C. Norcross, supra note 27, at 41 (Table 11). Studies have also shown that there is less resident participation in large homeowners' associations than in smaller ones. See CENTER FOR URBAN and Reg. Studies, U. of N.C., Evaluation of New Communities, Selected Preliminary Findings, Table 24 \& text at 28 (1974) [hereinafter cited as Evaluation of New Communities]. 
tionships is not substantiated by any relevant comparative research ${ }^{36}$ Finally, even when the tools of cooperation are made available, human factors might frustrate the entire scheme: apathy could plague the organization, ${ }^{37}$ and cultural differences could prove to be unbridgeable. ${ }^{38}$

There are also more tangible and perhaps more significant reasons for doubting the ability of the homeowners' associations to effect broad social change. Following legislation passed by Congress in 1968 and $1970,{ }^{39}$ the new town movement was hailed as a harbinger of social change. Promotional rhetoric often sought to identify the new towns with the popular myth of the New England town, ${ }^{40}$ the perfect community in which harmony and participation combined to create a laboratory of democracy. ${ }^{41}$ Homeowners' associa-

36 Indeed, one study that compared a development having a homeowners' association with a less comprehensively planned development lacking an association concluded that local involvement and neighborhood ties were no less evident in the latter. Zehner, Participation in Perspective: A Look at New Town Involvement, 12 Socrological Symposium 68 (1974). A comparison of two detailed accounts of life in new developments, the one run by a private organization and the other by public government (Radburn, New Jersey, and Levittown, New Jersey), indicates not only a similarity in the types of controversies that arose (e.g., over the sale of liquor and education) but also in the intensity of local involvement in settling the issues (although the solutions were different). Compare Ascher, supra note 2, with $\mathrm{H}$. GaNs, The LeVITTOWNERS (1967). For an account of residents' dissatisfaction in new communities see Evaluation of New Communities, supra note 35, table 26 at 29. See also text and notes at notes $46-47$ infra.

${ }^{37}$ See text at note 55 infra; cf. Ascher, supra note 2, at 300-01.

${ }^{38}$ The causes of several community conflicts in Levittown were traced by Gans, supra note 36 , to class differences. Controversies surrounding the educational system, budget priorities, liquor sales and the like often polarized the community along class lines and political affiliations.

${ }^{39}$ See Urban Growth and New Community Development Act of 1970, Title VI, Pub. L. No. 91-609, $\S \S 701-41,84$ Stat. 1770, and the overlapping New Communities Act of 1968, 42 U.S.C. $\S \S 3901-14(1970)$.

40 The historical background of the new towns reaches back to the "garden city" movement, first proposed at the turn of the nineteenth century in E. HowARD, Garden CiTIES OF To-Morrow (1946), first issued in 1898 under the title: To-Morrow: A PEAceful Path to REAL REFORM. Garden cities were intended to provide a new balance between city and country and to pave the way for a new civilization in which agricultural and industrial laborers would live in harmony with merchants and intellectuals. In 1929 the first deliberate attempt to implement the garden city idea was made in Radburn, New Jersey. See C. STEIN, Toward NEw Towns For AMERICA 37 (1966). Largely because of the Depression, however, the project failed to realize many of Howard's objectives for organization, population heterogeneity and size, and for the creation of an industrial base. See C. STEIN, supra; Ascher, supra note 2, at 285. In the thirties the "Greenbelt" developments, financed and run by the federal government, continued the movement, although in a much less ambitious manner. These developments, however, proved short-lived, and the garden city idea lay dormant for about three decades until it was revived in the sixties in response to the growing problems created by the massive exodus of both residents and industry from the core cities.

"The myth is debunked in K. Lockridge, A New England Town, The First Hundred YEARS (1970), in which the author shows that the elements of harmony and participatory democracy never really coexisted in these communities. 
tions, as an integral part of the new town strategy, became colored with similar utopian hopes.

In the 1960s the new towns were seen as one answer to the flight from the cities. While efforts were continued to strengthen the viability of urban centers, ${ }^{42}$ the proponents of the new towns saw them as vehicles to curtail urban sprawl, achieve dispersion of population, and revitalize the declining rural areas. ${ }^{43}$ To accomplish these goals, the new towns had to be self-sustaining, having their own industrial, commercial and cultural bases. Fascination with the ideal of a fresh start in new settlements prompted the selection of even more ambitious goals for the new towns, including the integration of different racial, class and age groups and the improvement of communication across these barriers. ${ }^{44}$ Community life was to be restored and the homeowners' association, as an antithesis to public government, became the symbol of the cooperation and close participation that would help eliminate rootlessness and transiency by cementing strong friendships and three-generation family ties. Intracommunity employment opportunities were expected to eliminate commuting and further enhance involvement and identification with the community. The natural environment was to be preserved. In short, the small New England town was to be re-created, albeit with all the modern conveniences. ${ }^{45}$

The record of the new towns in achieving these goals has been, to say the least, less than spectacular. Surveys in several privately developed new towns and two federally-assisted projects found that the median income and the percentage of blacks living in these communities resembled closely the statistics in regular suburban ventures and diverged widely from those prevailing in the standard metropolitan statistical area in which they were located. ${ }^{46}$ As in other suburban developments, the residents of the new communities were found to be mostly white-collar workers with above-average

${ }_{12}$ See Demonstration Cities and Metropolitan Development Act, 42 U.S.C. $\$ \S 3301-74$ (1970).

43 U.S. Advisory Comm. on Intergovernmental Relations, Urban and Rural America: Policies for Future Growth 99-100, 102, 149 (1968).

"See Mead, New Towns to Set New Life Styles, in New Towns - Why and For Whom? 117 (H. Perloff \& N. Sandberg eds. 1973).

${ }_{13}$ Cultural objectives were no less pretentious. In Columbia, Maryland, for example, the developer not only scheduled concerts but also tried to bring about greater cooperation between different religions and churches. See Wiggins, Organized Religion in Columbia: A Discussion of the Social Planning Process, 12 Sociological Symposium 55 (1974). As to different views of the success of that experiment, see id. at 61 .

" D. Lewis, A Comparative Analysis of Housing and Resident Characteristics in New Communities and Suburban Areas, table 4 at 18 \& table 7 at 30 (Preliminary Report, Center for Urban \& Regional Studies, U. of N.C. 1974). 
levels of formal education. ${ }^{47}$ This apparent failure to construct "socially balanced" communities may be attributed to a number of factors, ranging from lack of administration support and financial problems to local resistance to the introduction of low-income, nonwhite residents.

Even if the new towns had been successful in moving different groups of people to one location, it is questionable whether real communication across class lines would have been significantly improved. ${ }^{48}$ Racial and class prejudices might have produced strife within the community and might, as in several of England's and Israel's new towns, have caused the outmigration of one of the community's class groups. ${ }^{49} \mathrm{It}$ is within this context that the social impact of rising maintenance costs for the often superior recreational facilities in new towns should be considered. The limited number of members of "special target groups" who live in the new communities have undoubtedly improved their standard of living..$^{50}$ The problem is that low-income residents might not be able to enjoy the advantages of their community in the future, absent additional government subsidies. When maintenance costs rise, the homeowners' association must take one of two courses of action: raise the assessment charges or impose higher user fees. ${ }^{51}$ The latter approach might build walls of financial exclusion between the more and less affluent segments of the local population; a decision to increase fees has already caused bitter controversy in the Reston project..$^{52}$ The

47 Id. at 22 (table 5), 26 (table 6). See also the author's conclusion that "[g]iven the above profile and since central cities are becoming dominated by lower socio-economic status groups, it appears that with few exceptions neither new communities or high growth tracts are providing for these groups." Id. at 41.

13 An extensive study recently reported the following findings:

At present, the desirability of intervention to foster socioeconomic mixing in residential areas is uncertain. In question are not only the possible benefits but the untested assumptions concerning the amount and kind of present interaction across socioeconomic lines.

There is no evidence from field studies that socioeconomic mixing is feasible. The trend in the movement of urban population is toward increasing separation of socioeconomic categories. The tendency is manifested among blacks as well as among whites.

Advisory Comm. to the Dep't of Housing \& Urban Dev., Freedom of Choice in Housing, OPPORTUNITIES AND CONSTRAints 36 (1972).

"Alonso, The Mirage of New Towns, 19 The Pub. Interest 3 (1970).

so See generally Evaluation of New Communities, supra note 35, at 30 (table 28) (that finding relates to blacks and residents of subsidized building projects but not the elderly).

${ }^{3 t}$ A third and last resort would be to dedicate the facilities to the local (public) governmental entity. The problem is, however, that the dedication might be rejected and, if accepted, would open the facilities to the use of the public at large. See note 201 infra.

52 Washington Post, Jan. 16, 1975, \& A, at 5, col. 1. 
former might cause financial expulsion of the poor. The luxury facilities necessary to the financial success of the new towns might prove, therefore, to be a dubious blessing for social policy.

New towns have not lived up to expectations in other areas as well. First, research has shown that only 18 percent of the employed household heads in the new towns live and work there (as compared to 14 percent in similar "suburban developments"). ${ }^{53}$ Moreover, even if sufficient local jobs had been provided for the entire population, it seems unlikely that the employment picture in the new towns (most of which are located within commuting distance from one metropolis or another) would have been substantially different. ${ }^{54}$ Limited resident participation has also exploded the myth of participatory democracy: more than 55 percent of the members of the larger homeowners' associations did not attend even one meeting of the organization per year. ${ }^{55}$ Indeed, from all the available evidence, it appears that the most likely fate for the new towns is eventually to "blend into the landscape" and become indistinguishable from other suburban developments..$^{56}$

If this is the fate of the new towns, it seems highly unlikely that the record of other residential private governments will be any better: for, if the well-planned and subsidized new town projects could not effect social change, how will residential private governments in other developments be able to do so inadvertently?

\section{B. Private Controls, the Concept of Ownership and Personal Liberties}

Even if residential private governments had an ameliorative effect on community life, compulsory membership in a homeowners' association $^{57}$ would still place a severe strain on traditionally cher-

33 Evaluation of New Communities, supra note 35, at 24 (table 22).

31 Alonso concluded, on the basis of the European new town experience in preventing commuting by providing job opportunities within the community, that "[p]eople seem generally unwilling to constrain themselves to a localized and therefore small range of choices; and when feasible, they avail themselves of outside opportunities. It is extremely doubtful that new towns that are near metropolitan or other urban areas could maintain self-contained labor markets. .." Alonso, supra note 49, at 11.

ss Evaluation of New Communities, supra note 35, at 28 (table 24).

st See R. WARREN, supra note 32, at 369 . The death knell of the new town movement, which has already begun ringing, adds further support to this conclusion. HUD recently announced that it would not process any more applications for federal aid under the New Communities program. Wall St. J., Jan. 13, 1975, at 4, col. 3.

57 This skepticism is buttressed by some field research support. C. Norcross, supra note 27, at 8, states: "A major discovery of this study is how irritated and angry residents are with 
ished property rights. Although private, the residential private government comprises yet another layer of day-to-day regulation that further reduces those personal liberties defined in terms of property rights. The following section outlines an analytical approach to measure that reduction in property rights.

In the present section, Hohfeld's widely accepted model of ownership $^{58}$ will be used as a convenient framework for exploring the curtailment of traditional property rights under a residential private government scheme. Hohfeld conceptualizes ownership as a combination of four basic categories of legal relations: rights in the strict sense, privileges, powers, and immunities. Privilege is undoubtedly the key term respecting ownership in this formula. It denotes the sphere, however small, of individual dominium, the zone of "no rights" to others, the area of behavioral freedom. The other three terms apply this notion of dominium to other types of human interaction. Thus the duties of members of society at large to respect private territorial rights (trespass) and not to affect detrimentally the conditions within the boundaries (nuisance) are defined in terms of owners' rights; the right of the owner to change his legal relationships with respect to a particular object by transfer is defined in terms of a power; and the disability of others to tamper with the above-mentioned rights, privileges, and powers is defined as the owner's immunity.

The following brief description of several provisions often imposed on homeowners in residential private government communities $^{59}$ reveals the potential power of these organizations, the diminu-

the way their association is managed. Some are so bitter that they are selling their homes and moving away saying, "Never again!" 'See also id. at 81 (table 2). Only 39 percent rated the association performance as good; 42 percent rated it as fair and 19 percent as poor. The main reason is probably not related to the degree of services rendered for the monthly dues paid: examples of residents' reponses indicate that people greatly resent the association's controls over their home activities. Id. at 83-84.

${ }^{58}$ For Hohfeld's explanation of property rights in a nutshell, see Hohfeld, Faulty Analysis in Easement and License Cases, 27 YALE L.J. 66, $69 \mathrm{n.8}$ (1917); this formulation is embodied in the Restatement of Property §§ 1-4 (1936).

38 The account of restrictions in horizontal residential private governments is based on a review of the documents of the following new towns: Columbia, Md. (projected population 110,000), Reston, Va. (75,000), Jonathan, Minn. (49,900), St. Charles, Md. (75,000), Flower Mound, Tex. $(64,000)$, Maumelle, Ark. $(45,000)$, The Woodlands, Tex. $(150,000)$, Soul City, N.C. $(44,000)$, Beckett, N.J. $(60,000)$, and Litchfield Park, Ariz. $(75,000)$. The quoted provisions are usually not peculiar to a single project, appearing in the documents of several of the other above-mentioned communities as well. Differences do exist, however, between the various developments. The first two, which actually initiated the new town movement, did not receive aid from HUD. The other developments, with the exception of Beckett (commitment revoked, Jan. 1975) and Litchfield Park, received HUD's aid. It is clear, therefore, that the present review of homeowners' associations does not provide a 
tion in traditional ownership rights that results from the exercise of that power, and the possibilities of abuse that arise from the growing reliance on executive discretionary powers.

Owners' privileges are curtailed in various ways. Large communities are often privately zoned for specific uses, and the erection of structures is further restricted, in some cases, by such requirements as minimum floor area, set-back lines, maximum height and minimum value. The modern attitude is to vest an almost unlimited discretion in an architectural control committee to pass upon building plans. The committee is usually empowered, not only to decide whether the proposed house is "harmonious" with the neighborhood, but also to review minor details. ${ }^{60}$ Cases in which a particular exterior paint was insisted upon, certain building materials re-

balanced picture, dealing mainly with large projects whose legal arrangements were reviewed by HUD. Thus two additional sources were consulted: the restrictions imposed in the Radburn, N.J., project (established in 1929), see A. Dunham, Modern Real Estate Transactions 147-66 (1952), and the model forms in The Homes Association HandBooK, supra note 10, at 384-402 (Appendices F, G \& H). The comparison revealed a substantial similarity between many of the new town provisions and the documents prepared for smaller private governments. As to condominiums, two major works containing model forms were used, and several documents used in condominiums in the Chicago area were reviewed. All of the restrictions mentioned below do not, however, appear in each individual project.

"Section 7.10 of the Soul City "Declaration of Covenants, Restrictions, Easements, Charges and Liens" declares, for example, that the architectural committee ". . . shall have the right to disapprove any plans and specifications . . . for the following reasons, among others:

(3) failure to comply with any of the rules and regulations promulgated [by the committee itself] pursuant to this Article;

(4) Objection to the exterior design, appearance or materials of any proposed Structure or Improvement;

(5) incompatibility of any proposed Structure . . . upon any lot or with reference to other Lots in the Property;

(8) objection to the color scheme, finish, proportions, style of architecture, height, bulk, safety or appropriateness of any proposed Structure or Improvement;

....

(10) any other matter which, in the judgment of the [committee] . . . would render the proposed Structure . . . Improvement . . or uses incompatible with the general plan ... ;

(11) any matter not included in the rules or regulations, or an amendment to or revocation of such rules and regulations, if in the judgment of the [committee] . . . such matter would not be in the best interest of the Property.

Similar provisions are found in most of the other new towns mentioned in note 59 supra. In others it is simply stated that a plan may be rejected for failure to comply with the declaration or regulations or "any other matter which, in the judgment of the [Committee], could render the proposed Structure(s) or use(s) inharmonious with the general plan of improvement of the area or with Structure(s) located upon or use(s) located upon other lots in the vicinity." Section 6.11, Flower Mound, Texas, Declaration of Covenants, Restrictions, and Easements. 
quired, and the design of certain awnings was vetoed are reported.61 Building permits must often be obtained before a garage may be enlarged, a doghouse built or fence erected.62 The owner may also be restricted in the use of his yard. Unscreened storage of goods and certain movables is often prohibited ${ }^{63}$ trees may not be cut without permission, ${ }^{64}$ and signs, above-ground pipes, antennas and the like are similarly restricted. In several new towns it is provided that "[e]ach owner shall keep and maintain all Lots and Structures owned by him in good condition and repair, including but not limited to: the seeding, watering and mowing of all lawns; the pruning and trimming of all trees, hedges and shrubbery so that the same are not . . . unattractive in appearance; and the repairing and painting . . . of all structures." leges" replaced by an affirmative duty, but the standard of performance is, as will shortly be seen, determined entirely by the association's board.

Restrictions may also apply to activities conducted within the confines of the home itself. Certain household equipment is banned unless a license is secured, ${ }^{66}$ the keeping of pets is regulated, and occupational activities, however harmless they might be, require a

a1 The restrictions outlined in the following cases are typical: Kirkley v. Seipelt, $212 \mathrm{Md}$. 127, 128 A.2d 430 (1957) (unsightly awnings); West Hill Colony, Inc. v. Sauerwein, 78 Ohio L. Abs. 340, 138 N.E.2d 403 (Ct. App. 1956) (color of exterior paint); Lewis Manor Land Co. v. Long, $17 \mathrm{~Pa}$. D. \& C.2d 431, $106 \mathrm{~Pa}$. L.J. 381 (1958) (building materials).

22 See Hollingsworth v. Szczesiak, 32 Del. Ch. 274, 84 A.2d 816 (1951) (size of garages); University Gardens Property Owners Ass'n v. Solomon, 88 N.Y.S.2d 789 (Sup. Ct. 1946), 18 A.L.R.3d 853 (doghouses).

${ }^{e 3}$ Section III(e) of the Jonathan, Minn., Single Family Residential Standards, Covenants, Conditions, and Restrictions is typical. It provides that

[o]utside storage of any items shall not be allowed unless screened from view by enclosures so as to effectively screen such storage from view outside the Site. The design of such screened enclosure must be approved.

In several communities, specific absolute restrictions prohibit leaving particular movables, such as trailers, recreational vehicles and boats, in the yards.

" Section 10.02 of Maumelle's Bill of Assurance and Declaration of Covenants, Easements, Charges and Liens states, for example, that

No living tree having a diameter of six (6) inches or more (measured from a point two

(2) feet above ground level) shall be removed from any Lot without the express written authorization of the [Architectural Review and Design Committee].

65 Section 8.09, Flower Mound, Texas, Declaration of Covenants, Restrictions, and Easements.

"Id., section 8.08: "No machinery shall be placed or operated upon any Lot . . . including air conditioning and heating units, except such other machinery as is usual in the physical maintenance of such Structure, without . . . prior written approval . . . " St. Charles, Md., incorporated into its covenants detailed standards regarding noise pollution (section 4.15) following HUD's circular No. 1390.2, Noise Abatement and Control (1971). 
permit. ${ }^{67}$ Although the right to use the common facilities is considered an easement appurtenant to the property, it may be suspended if the private government "officials" decide that the homeowner in question has violated the regulations. ${ }^{68}$ In condominiums, restrictions on the number of persons permitted to live in an apartment, hours during which music may be played, the hanging of shades, the use of electrical equipment and the like are common. ${ }^{69}$ More detailed regulations usually apply to common facilities. ${ }^{70}$

The second category in Hohfeld's model is that of ownership rights, the most common characteristic of which is the right to protect one's property from intruders. The law has traditionally considered this right to be so important that self-help is permitted, ${ }^{71}$ and the action of trespass may be brought even though no damage either has occurred or will occur. ${ }^{72}$ Yet in several new towns the association's articles specifically declare that if the directors (or the architectural committee) decide that the local regulations have been violated by the erection of a structure without a permit, neglect of the garden or storage of movables in the front yard, the association is permitted to enter the member's land without a court order, demolish improvements, carry out gardening work and cart away the movables, charging the owner for the expenses incurred. ${ }^{73}$ Similar

"See, e.g., section 13.02 of the Woodlands Covenants, Restrictions, Easements, Charges and Liens:

No profession or home industry shall be conducted in or on any part of a Lot or in any improvement thereon on the Property without the specific written approval of the [Development Standards Committee].

is The following provision is rather common:

The Members' rights and/or easements of enjoyment of the Common Area . . . shall be subject to . . . (b) . . . the right of the Association to suspend the right of a Member or the right and easement of an Owner to use the recreational facilities for a period not to exceed sixty (60) days for any . . . infraction of this Declaration or the Book of Resolutions."

Article III, Section 3, Beckett, N.J., Declaration of Easements, Covenants and Restrictions.

" See M. Reskin \& H. SaKai, Modern Condominium Forms $\$ 5.14$ (rules 24, 3, 14, 16 in particular) at 5-81, -84.

io See id. rules $6,17,18$ and $\S \S 5.15,-.16$, at $5.85-.86$.

7 W. Prosser, HaNdBook of the LaW of Torts 113-17 (4th ed. 1971).

72 Id. at 66.

${ }^{73}$ Section 14.01(a) of Flower Mound, Texas, Declaration of Covenants, Restrictions, and Easements provides:

In the event of a violation or breach of any covenant or restriction contained in this Declaration, . . . the Association shall give written notice to the Owner setting forth . . . the specific . . . actions needed to be taken to remedy such violation or breach. If the Owner shall fail to take reasonable steps to remedy such violation or breach within twenty (20) days after the mailing of said wtitten notice, then the Association shall have ... the right . . . through its agents and employees to enter at all reasonable times upon any Lot or Structure . . . and take the actions specified in the notice . . . without 
provisions are contained in the homeowners' association charters of several condominiums in the Chicago area. Under the rubric of "abatement of nuisance" the homeowners' organization is empowered to enter apartments forcibly, correct what they consider to be violations of the regulations, and collect the cost of such action, all without prior litigation. ${ }^{74}$ Conversely, in some developments there are provisions designed to prevent the homeowner, although only temporarily, from going to court to enforce the servitudes that run in his favor. ${ }^{75}$

The powers of individual owners are likewise restricted in residential private government communities. The subdivision of lots is generally prohibited. In condominiums, sales and leases are often subject to approval by the directors. When title is acquired by a new owner through gift, devise, or inheritance, the homeowners' organization has the power to compel him to convey the apartment to itself. ${ }^{76}$ Other provisions sanction compulsory sale, albeit through

being deemed to have committed a trespass or wrongful act . . . and with the cost thereof to be a binding personal obligation of such Owner . . . as well as a lien on such Owner's Lot . . . .

This section applies to building violations as well as "gardening" and other minor violations. The drastic sanctions outlined above (including the demolition of structures) were found in the documents of all the new towns reviewed (see note 59 supra) with the exception of Jonathan, Minn. (which apparently requires a court order) and Litchfield Park, Ariz. (which apparently does not contain specific use restrictions and architectural controls). In Reston, Va., and Radburn, N.J. (see note 59 supra) a court order is necessary to take action against building violations, but "self-help" is permitted to correct maintenance violations.

74 Section 11.01 of the Declaration of Condominium Ownership and of Easements, Restrictions, Covenants and Bylaws for Harbor Drive Condominium Association [hereinafter cited as the Harbor Drive Declaration] (a new condominium project on Chicago's lake front containing over 740 units in a single building) provides, for example, that in the event a violation is not corrected within ten days after a notice is given, the association has the right:

to enter upon that part of the Property where such violation or breach exists and summarily abate and remove, at the expense of the defaulting Owner, any structure, thing or condition that may exist thereon contrary to the intent and meaning of the provisions hereof. . . . All expenses . . . in connection with such actions . . . shall be charged to and assessed against such defaulting Owner . . . and deemed part of his respective share of the common expenses.

75 Section 5.1 of the Litchfield Park Declaration provides:

The Association, as the agent and representative of the Owners, shall have the exclusive right to enforce the provisions of this Declaration. However, if the Association shall fail or refuse to enforce . . . for an unreasonable period of time, then any Owner may enforce them on behalf of the Association.

36 See, e.g., 1 A. FERRER \& K. STECher, supra note 5, at 521-26 (Form 51). The right of first refusal has been extensively dealt with by the legal literature and will not be discussed in the present paper. See generally 1 P. Rohan \& M. Reskin, Condominium Law and Practice $\S 10.03$ (1974); Berger, Condominium: Shelter on a Statutory Foundation, 63 Colum. L. Rev. 987, 1017-19 (1963); Boyer \& Spiegal, Land Use Control: Pre-emptions, Perpetuities and Similar Restraints, 20 U. Miami L. Rev. 148 (1965); Browder, Restraints on the Alienation of Condominium Units (The Right of First Refusal), 1970 U. ILL. L.F. 231; Moller, The Condo- 
court procedure, of units whose owners violated the rules of the association. ${ }^{77}$

Finally, there is the category of immunities. According to Hohfeld's definition, liabilities are the perfect negative of the owners' immunities. The most important specific liability under the new community regime is the assessment which the association is empowered to collect for the purpose of financing community services. Each owner is personally liable for such debts, and the arrears are secured by a first lien on the land. Yet the homeowners cannot be sure how the money will be spent. ${ }^{78}$ The association might be required to provide certain services, but the quality of those services and the fate of any surplus funds are left entirely to the discretion of the directors.

Beyond these explicit regulations set forth in the homeowners' covenants or articles of association, there is the ever-present possi-

minium Confronts the Rule Against Perpetuities, 10 N.Y.L.F. 377 (1964); Note, Condominiums and the Right of First Refusal, 48 ST. JoHN's L. REv. 1146 (1974); Note, Right of First Refusal-Homogeneity in the Condominium, 18 VAND. L. REv. 1810 (1965).

$" 7$ For example, section 11.02 of the Harbor Drive Declaration, supra note 74, provides: Involuntary Sale. If any Owner (either by his own conduct or by the conduct of any other occupant of his Unit) shall violate any of the covenants or restrictions or provisions of this Declaration or the regulations adopted by the Board, and such violation shall continue for thirty (30) days after notice in writing from the Board, or shall recur more than once after such notice, then the Board, shall have the power to issue to the defaulting Owner a ten (10) day notice in writing to terminate the right of said defaulting Owner to continue as an Owner and to continue to occupy, use or control his Unit and thereupon an action in equity may be filed by the members of the Board against the defaulting Owner for a decree of mandatory injunction against the Owner or Occupant or, in the alternative, a decree declaring the termination of the defaulting Owner's right to occupy, use or control the Unit owned by him on account of the breach of covenant and ordering that the right, title and interest of the Owner in the Property shall be sold . . . at a judicial sale upon such notice and terms as the court shall establish, except that the court shall enjoin and restrain the defaulting Owner from reacquiring his interest in the Property at such judicial sale.

Note that this clause covers every violation and not only default on the assessment payments. Similar provisions were found in several other condominium documents in the Chicago area.

${ }^{78}$ Provisions like the following are common in new town documents:

The general assessment levied by the Association shall be used exclusively to promote the recreation, health, safety and welfare of the Residents of the Property and in particular for the improvement, maintenance and operation of the Common Area, facilities and programs.

Beckett's Declaration of Easements, Covenants and Restrictions, Article IV, Section 2(a). Almost identical language is used in Article V, Section 2, of the Model Form: Declaration of Covenants and Restrictions, The Homes Association HandBook, supra note 10, (App. F.) at 389. In the Radburn, N.J., provisions the absolute discretion of the Board of Trustees is explicitly emphasized. See Radburn's Declaration in A. DunHam, supra note 59, at 157-58.

It should be noted, however, that the association is usually under a duty to keep the "common area . . . in good, clean, attractive and sanitary condition . . ." Beckett's Declaration, Article III, Section 1. 
bility of new regulation. So far as the legal instruments of residential private governments are concerned, the owner's privileges are merely conditional. Ownership and life in the community are totally subordinated to whatever rules are proclaimed by the homeowners' organization..$^{79}$ Unlike local municipal governments, which are restricted by federal and state laws, constitutional standards and administrative norms from impairing private ownership beyond a certain point, the laws of the private residential government rarely include any substantive criteria to limit future "legislation." The only safeguards provided are procedural in nature: all decisions must be made by a majority and a "supermajority" is required on some matters. ${ }^{80}$ The only restrictions within the system may be found in the articles of association, and they are broadly drafted. The promotion of health, safety, the common good and social welfare is almost always declared as the primary objective, suggesting that the homeowners' organization claims to possess at least the same powers that municipalities have-without the concomitant limitations of public law. ${ }^{81}$ Adjusted as they are to a climate of regulated living, it would not be surprising if the majority opted for further regulation, whether in the form of explicit prohibitions or further enlargement of discretionary powers. Thus, given the existing and potential encroachments on ownership rights, it is clear that the concept of ownership under residential private government rule deviates significantly from the theoretical model of traditional property rights.

The situation described above raises two distinct questions. The first is the problem of abuses. Once the legitimate purposes of the homeowners' association are defined, abuses can be easily identified. The possibilities for abuse in a residential private govern-

79 The declarations of new towns receiving a federal guarantee or grant provide that no amendments are allowed during the development period without the approval of HUD.

so The arrangements regarding amendments in the declarations vary. In Reston, $\mathrm{Va}$., for example, after the development period, a vote of 50 percent plus one vote is sufficient except as to certain matters (e.g., assessments, membership) as to which 10 percent of the members have a veto power. In the Woodlands, Texas, development $662 / 3$ percent are required for all the amendments to the declaration.

${ }^{81}$ In federally-assisted new towns covenants intended to provide equal housing opportunity are incorporated as well as general no-discrimination clauses. Some provide that the association is not able to undertake any action which, if taken by a state, would violate the fifth or the fourteenth amendments.

In the articles of incorporation of Litchfield Park, Arizona, it is provided that the association shall have the power "[t]o do any and all things authorized under the Charter of the City of Phoenix, Arizona, as amended from time to time . . . A Article IV(t). The following provisions, however, make it clear that the association's powers are not to be limited to those granted the government of the city of Phoenix. 
ment are numerous: permits may be granted in exchange for bribes or denied in response to the interference of an influential neighbor, assessments may be misused to benefit only a small group or for purposes unrelated to the community's welfare, "undesirables" may be harassed, and the assessment system may be manipulated to force out the lower income segment of the population. Given the ever-present shadow of discretionary power and the fact that a simple majority may dispense with minority rights, there is always a danger of arbitrary decision making. The second question concerns the scope of the association's power: assuming that a specific measure is within the orbit of the association's legitimate purposes, could it nevertheless be invalidated for being too great an encroachment on ownership privileges? In other words, should protective boundaries be established as a matter of law?

\section{Private or Public Law Regulation?}

We are all apprehensive of interference with private property by the public government, but to this point at least, most commentators have failed to notice that property rights may also be seriously threatened by the powers of the residential private government. Although additional areas of conduct have constantly been taken over by government regulation, the sensitivity of the subject has always triggered public debate and tempered evolution, producing reforms in administrative policies and procedures as well as the growth of judicial scrutiny. No such discussion has begun as yet on the issue of residential private governments.

The proposition that public law principles of constitutional and administrative law should be applied by analogy to regulate the affairs of the residential private government ${ }^{22}$ is, at first blush, tempting. Simply erasing the word "private" seems to open a gate to a wonderland where the solution to every problem is readily available. This short-cut, however, would be undesirable both on analytical and practical grounds.

\section{A. Public Law Regulation}

There are perhaps many situations in which a homeowner might argue that the residential private government, which holds so much power over him and his property, should be subject to the

${ }^{2}$ See Chicago Comment, supra note 3; Note, New Community Development, 11 WASHBURN L. J. 227 (1972). 
constitutional restrictions of the fourteenth and fifth amendments. ${ }^{83}$ Such an argument would, however, be open to serious objections. First, the conventional concept of state action does not seem to apply to the residential private government: it is not a government agency in private law clothes, and significant state involvement in the creation or operation of the organization cannot usually be demonstrated..$^{84}$ Second, even if there is state action under the attenuated definition of that concept in Shelley v. Kraemer ${ }^{85}$ and Marsh $v$. Alabama, ${ }^{86}$ there seems to be no constitutionally protected right that a homeowner could assert against a residential private government operating within the constraints of its own rules.

In Shelley, racially restrictive covenants were struck down in order to vindicate the constitutional rights of the third-party black petitioner; the court, however, assumed that the promisor's obligation would be valid. Similarly, in Marsh the first amendment rights of an outsider were held to override the property rights of the owner of the company town. Neither Shelley nor Marsh dealt with a situation, like the present one, in which a person was attempting to avoid his voluntarily assumed obligations because they violated his constitutionally protected rights.

The key term here would seem to be "voluntary." Currently, only a small percentage of the housing market is operated under a residential private government system. Home buyers, generally people of some means who can be expected to take care of themselves, therefore have a real choice as to whether or not to join such a community. And, if residential private governments ever became so widespread that this choice disappeared, it is likely that consumers would become more sensitive to the legal structures of their com-

${ }^{*}$ See, e.g., Henlopen Acres, Inc. v. Potter, 36 Del. Ch. 141, 127 A.2d 476 (1956) (unsuccessful attempt to challenge a residential private government's "taxation" system on constitutional grounds).

st Usually the residential private government's only contact with state agencies is in the planning and licensing stages; these stages, which concern the developer, are not relevant to the homeowners' assocation. In any event, licensing and state regulation per se do not subject private organizations to constitutional requirements. Jackson v. Metropolitan Edison Co., 419 U.S. 345 (1974); Moose Lodge No. 107 v. Irvis, 407 U.S. 163, 171-77 (1972).

${ }^{85} 334$ U.S. 1 (1948). This would seem to be a rather dubious assumption, however: the authoritative value of Shelley seems to be quite low both because of its confusion of the judiciary as an institution with the judiciary as the enforcer of private transactions and because of the refusal of the Court to apply it to matters other than racial discrimination. For a thorough analysis of the Shelley puzzle, see Henkin, Shelley v. Kraemer: Notes for a Revised Opinion, 110 U. PA. L. REv. 473 (1962).

s6 326 U.S. 501 (1946). The Marsh v. Alabama doctrine has also been limited recently. See Jackson v. Metropolitan Edison Co., 419 U.S. 345 (1974); Lloyd Corp. v. Tanner, 407 U.S. 551 (1972). 
munities and that developers would respond accordingly by varying those structures. In this atmosphere of voluntary transactions in a competitive market, constitutional guarantees seem singularly out of place. Where a person voluntarily agrees to allow his rights to be affected by others, according to a certain procedure, a court should not entertain a subsequent challenge that the use of such a procedure deprived him of property rights without due process of law. Perhaps more important than the question of state action or the ability of a homeowner to show a violation of a constitutionally protected interest, however, are the wide implications of adopting public law regulation of residential private governments.

The imposition of constitutional and administrative law standards on the residential private government would be motivated by a concern for the personal liberties of the minority. Yet this approach, instead of remedying specific problems, would impose on the associations an entire regulatory framework requiring conduct to proceed along prescribed lines. Unnecessary to the point of "overkill," such regulation would only increase the already undesirable gravitation toward central control and uniformity of conduct. Protecting property owners from the consequences of their transactions would imperil the freedom to transact. A severe curtailment of the liberties of both the developers and the majority of the homeowners would result, and thus the problem of diminishing property rights and personal liberties would be exacerbated. The "public law route" might therefore ultimately erode, rather than vindicate, constitutionally protected property rights.

Moreover, it is difficult to determine how the decision to apply public law concepts to residential private governments would be implemented. There is a problem, first, concerning which associations would be regulated in this fashion: should we opt for an arbitrary indicator of size such as, for example, fifty units or is inquiry into the rules of each organization preferable? Second, it is unclear how the necessary rules and regulations would be tailored to fit the various types of associations. Should all the rules of administrative law be deemed relevant or only constitutional norms? Perhaps some of the applicable rules would be mandatory, while others would be considered implied terms that could be contracted out of. Third, there is the question of enforcement: should transactions that fail to comply with public law requirements be illegal, invalidated in part, or corrected by the courts? ${ }^{87}$ Finally, what are the implications

$"$ If the private nature of the residential private government is to be ignored, could it not be argued that the homeowners' organization, being a "local government," has inherent 
of this public law regulation of private conduct for other traditionally private areas such as corporations, voluntary associations and religious establishments?

These few observations should serve to indicate the nature of the problems that would accompany an attempt to use public models to regulate residential private governments. It is unnecessary to confront these problems in greater detail, however, so long as private law concepts remain to be applied. The functional similarity between homeowners' associations and municipalities should not be the only element considered; an analysis of the organization's legal structure is indispensable. That is particularly true where the legal form adopted adequately represents the intentions of the parties involved. Difficulties might arise when existing legal institutions are used for purposes other than those for which they were originally designed; existing patterns are often incapable of accomodating socially revolutionary ideas. For example, the operation of a socialistic commune, organized as a corporation, could be attacked on the grounds that it was not conducted in a way intended to yield profits to the members. ${ }^{88}$ The disparity between capitalistic aims, implied by the organizational form, and the communal way of life actually intended would be unbridgeable. Similar problems are faced by modern communes that are variously organized as trusts, charitable institutions and corporations-none of which adequately correspond with the role of the group as understood by its members. ${ }^{89}$ In all such cases, traditional analysis would be unsatisfactory. Because it is a typical product of the mainstream of the present culture, however, the residential private government movement does not pose such problems. The legal means employed to establish the association are intended to serve traditional interests in holding and enjoying private property, and they generally fit the ends sought. The new context and the enlarged scope of residential private governments undoubtedly raise new issues. But these problems are the familiar ones that the private law was designed to deal with.

\footnotetext{
powers and indeed is under a duty to promote the welfare of the community, employing police power even where the covenants do not provide for it? If the problems mentioned in the text should become a subject of public regulation, then, concurring with Professor Wechsler, I ". . . prefer to see the issues faced through legislation, where there is room for drawing lines that courts are not equipped to draw." Wechsler, Towards Neutral Principles of Constitutional Law, 73 Harv. L. REv. 1, 31 (1959).

${ }^{8 s}$ In such a case, Allen v. Llano Del Rio Co., 166 La. 77, 116 So. 675 (1928), the court dismissed the action brought by a former member of the community on the grounds of estoppel. For a description of this community experience, see P. Conkin, Two Paths to Utopia (1964).

"so See R. KANTER, supra note 34, at 173.
} 


\section{B. Private Law and a Theory of Property Rights}

The residential private government system (in horizontal communities at least) is based on both the law of servitudes ${ }^{90}$ and voluntary associations. The developer imposes a "general building scheme" on his assembled lands, which includes specific restrictions and provides that the powers described above ${ }^{81}$ will be vested in a homeowners' association; the recorded documents further provide that each owner will automatically become a member in the association upon the purchase of his land. At the same time, certain lots, designated for community facilities, are transferred to the organization subject to the user rights of the residents. All of these elements are in line with traditional property practice; the new element introduced by the residential private government movement is the grant of comprehensive powers to the association. These powers include the right to impose new restrictions, amend or annul old ones, apply and specify the standards of existing restrictions (for example, architectural controls), perform certain acts on owners' lands, and suspend or extinguish the residents' rights to enjoy the community facilities. We are faced, therefore, with a novel planning device that may best be described as a "discretionary servitude." It is by virtue of such servitudes, which "run with the land" and bind subsequent purchasers, that the residential private government is able to exercise its coercive power. The voluntary association structure facilitates democratic participation, but without the property law foundation provided by the servitudes homeowners would be free to leave the organization whenever they chose-thus gaining immunity from the decisions of that group, while remaining residents in the community. ${ }^{92}$ Discretionary servitudes are, therefore, the key to the

90 The term "servitudes" as used in this paper refers to easements, restrictive covenants and equitable servitudes. For an argument, based on historical and functional analysis, that all three forms should be treated as one concept, see U. Reichman, Servitudes in Residential Private Government Systems 92-187, December 1975 (unpublished thesis in The University of Chicago Law School Library).

"See Section II supra.

22 It might be argued that servitudes provide only the means of compelling owners to become members of the association, and thereafter the organization's powers are derived from its constitution and bylaws. Even if the purchase of land encumbered with such a duty were described as an implied consent to become a member, it is inconceivable that involuntary membership in a voluntary association could be maintained. Furthermore, such an obligation would seem to fall before the "touch and concern" test. Cf. Petersen v. Beekmere, 117 N.J. Super. 155, 283 A.2d 911 (Super. Ct. Ch. 1971). But see Lincolnshire Civic Ass'n v. Beach, 46 App. Div. 2d 596, 364 N.Y.S.2d 248 (1975). Other cases have invalidated such obligations for different reasons. See Kenney v. Morgan, 22 Md. App. 698, 325 A.2d 419 (Ct. Sp. App. 1974); Mountain Springs Ass'n v. Wilson, 81 N.J. Super. 564, 196 A.2d 270 (Super. Ct. Ch. 
proper functioning of the entire residential private government system. ${ }^{93}$

Before reaching a more detailed and technical discussion of these legal arrangements, a basic policy issue must be confronted. The above description of ownership rights within the Hohfeldian construct is somewhat misleading if taken at face value, for the apparent diminution in property rights is itself a product of the exercise of an ownership power-the power to create interests in land. The powers granted to the homeowners' association are a product of the property owners' freedom to transact; when dissident members seek release from what they consider to be a burdensome exercise of those powers, they are, in effect, seeking freedom from transaction. Property law has long been concerned with striking an appropriate balance between these two opposing "freedoms." In order to fashion a policy rationale for placing limits on the power of the residential private government, it is necessary to return to the policies behind traditional property law, considering the intentions of the parties and the function of ownership and servitudes.

Property law provides a striking example of an area in which terminology remains constant, even while its meaning and the justifications for retention fluctuate from age to age. Thus, the inquiry will be approached from two different directions: first, from the point of view of those commentators who perceive property rights as instruments to facilitate economic efficiency and, second, from the more traditional perspective of those who equate property rights with personal liberty.

1. Economic Efficiency. Economically-oriented commentators argue that the common law system of property evolved in response to the need to allocate land resources efficiently.$^{94}$ For example, efficient land use would be impossible without rules establishing certainty in transactions between owners of separate parcels. ${ }^{95}$ Under this analysis, the only legitimate purpose for bringing the

1963). The drafting practice is not to impose a membership duty but rather to subject owners to certain obligations (such as servitudes) regardless of whether they remain members or not.

${ }^{23}$ This is not to say, however, that the law of servitudes is the sole possible source for regulating residential private governments. Voluntary associations law could provide additional restrictions; see, for example, the discussion of the consequences of deviation from proper bylaw procedures in Gerde v. Simonson Investments, Inc., 197 So. $2 \mathrm{~d} 754$ (La. Ct. App. 1967). Property law devices other than servitudes, such as conditional estates, are also used in the residential private government context; they merit separate consideration.

"s See, e.g., R. Posner, Economic Analysis of Law 10 (1973).

${ }^{\circledR 5}$ See generally id. at 10-21; Coase, The Problem of Social Cost, 3 J. LAW \& EcoN. 1 (1960). 
different owners under the organizational roof of the private residential government would be to achieve an overall maximization of benefits. By purchasing a home in a residential private government community, the owner waives part of the incidents of his title; he is compensated for this diminution of his rights, however, by the generally improved living conditions and the extra services provided for all the members of the community. According to this approach, a certain degree of compulsion is essential and legitimate: it would be intolerable if one owner could veto all regulatory changes (as he could with regular servitudes). Unless all must abide by the decision of the majority, the contemplated improvement in the standard of living could not be achieved except by purchasing the consent of the uncooperative owner. Within this framework, an "abuse" would be defined as any action that reduced the efficient operation of the association. Thus, a decision to provide special benefits to a single person or a small group, by depriving others or by reducing the association's ability to provide general services, would defeat the legitimate purpose of banding together and would constitute an abusive exercise of power.

The problem of establishing "boundary lines" by reference to the criteria of efficiency is more troublesome. It could be argued that individual submission to the will of the majority is a necessary cost of obtaining better services. If a homeowner is consistently offended by the decisions that are reached (decisions that are not "abuses" as that term is defined above) he is probably incompatible with the community; eventually he and other dissenters will move, and by a process of sales the market mechanism would finally bring about a certain degree of harmony. If the purpose of the community venture were only to maximize services while minimizing costs, this argument would be persuasive. But there is an additional purpose to a homeowners' association: to increase the overall enjoyment of the community. ${ }^{96}$ This purpose could not be satisfied by merely numerical majority decisions. The betterment must be weighed against the outrage or suffering caused by each intended measure in light of the feelings of all persons involved and the effect the decision may have on future community relations. In the absence

" That impressive structures and services cannot compensate for the deprivation of personal liberties is probably best illustrated by the experience of Pullman, Illinois. This company town provided a range of excellent services and was highly progressive in architectural terms. The international awards granted to the town for architectural achievements, however, could not cover up the fact that it was totally subordinated to the will of one man. This domination was probably a contributing factor to the outbreak of the notorious Pullman strike. A. Lindsey, The Pullman Strike 63-65, 85-86, 90-91 (1942). 
of a device capable of measuring these sensitivities, one could make a case for resorting to definite rules to prohibit certain typical "outrageous" interferences with ownership privileges. ${ }^{97}$

It is true that the common law invalidates certain transactions that tend to produce grossly inefficient uses of land. Thus, the rules against perpetuities and against restraints on alienation could be explained as devices to allow the shifting of land resources to their most efficient use..$^{88}$ Similarly, the "touch and concern" rule, which prevents certain types of obligations from being attached to land, could be seen as a barrier to undesirable "tie-in" arrangements. By invalidating, for example, a servitude designed to require an owner to purchase goods and services from only a certain supplier, the waste of resources is prevented and the free competitive functioning of the market is facilitated. Where the economic analysis breaks down, however, is where the costs of binding people to their transactions must be measured in terms of intangibles, such as personal unhappiness. It would seem rather far-fetched to argue that in such cases the system protects incidents of ownership, notwithstanding a transaction to the contrary, in order to achieve a cost-justified result.

Calabresi and Melamed's discussion of a similar question ${ }^{99}$ illustrates this difficulty. They suggested that although rules of inalienability, which prohibit the sale of certain rights, are imposed for moral or paternalistic reasons, they serve the purpose of overall

$"$ Cf. Michelman, Property, Utility, and Fairness: Comments on the Ethical Foundations of "Just Compensation" Law, 80 HaRv. L. Rev. 1165 (1968). In our case we are dealing with problems within a small community. Members of society at large (following the utilitarian theory) would not feel threatened by an encroachment on property privileges imposed by a majority decision under a particular arrangement in a certain development. Within the community itself the relationship between the benefits obtained by the restriction and the outrage caused by the same restriction could theoretically be measured by using an objective denominator (money). Following Michelman's approach, the action would be deemed permissible only if the sum that the supporters of the measure would be willing to pay exceeds the sum that the objectors would insist upon as the price of agreeing to the adoption of the measure. Since no compensation is ever to be actually paid, however, the "demoralization cost" has to be considered alongside the "efficiency gains" described in Michelman's article. See id. at 1214.

98 See R. Posner, supra note 94, at 13.

" Calabresi \& Melamed, Property Rules, Liability Rules, and Inalienability: One View of the Cathedral, 85 HARv. L. Rev. 1089 (1972). The question in our case, however, is different. It is not whether an owner can be prohibited from transferring some of his ownership rights, but rather whether interests in rem may be molded at will. It is not the intention of the immediate party to the transaction that is taken into account by a prohibition on forming unique interests in land but the property regulations that would be binding on a stranger. In another sense, the question is what incidents of ownership must follow from a conveyance of title. 
efficiency as well. But to argue as they do that (a) if certain transactions were allowed many people would be upset and (b) thus would be willing to pay more money to the seller for not consummating the deal than he could have otherwise obtained, but that (c) prohibitive transaction costs make such an outbidding procedure impossible and therefore (d) the law invalidates these types of transactions ${ }^{100}$ - seems not only highly artificial but also without any foundation in the law. The trouble with this approach is that it insists on justifying the application of certain restraints, imposed by the legal system as a protection of individual rights, by reviewing the economic impact of the rule on society at large. The fact is that the law is based on the assumption that restrictions are essential to ensure human well-being, dignity and freedom; historically, there has been no need for any further justification.

2. Personal Liberty. Pound once noted that "[f]rom the time when men began to think about rights and formulate declarations of liberties . . . they have put property . . . along with liberty in the forefront," and he added, "for a long time liberty and property seem one conception." 101 The relation between the two terms received different explanations and justifications in various periods of Western thought, ${ }^{102}$ but in American tradition they are invariably intertwined. The idea that property rights protect personal liberties is reflected in the Constitution, court decisions and writings throughout the history of the nation. ${ }^{103}$ Yet the degree of protection

100 The achievement of that objective by liability rules is discarded by the authors since the harm "does not lend itself to an acceptable objective measurement." Id. at 1112.

${ }^{101}$ Pound, The Law of Property and Recent Juristic Thought, 25 A.B.A.J. 993, 994-95 (1939).

102 In the Middle Ages jurists thought about liberties. In the seventeenth century they began to think about rights. They took rights to be qualities of persons which made it just that they have certain things or do certain things, thus joining liberty and property in one conception. Hence the first modern philosophy of rights, though it included property, was at bottom a philosophy of personality, finding a basis for property in the qualities of a person. Later liberty and property were conceived of as resting upon contract, and so ultimately on the inherent moral binding force of a promise. We are all bound by an original contract to live together in a politically organized civil society in which liberty and property were guaranteed. The nineteenth century . . . built contract upon property and property upon liberty. The fundamental idea was one of the maximum of free individual self-assertion as the end of the social and legal order. Id. at 995 .

${ }^{105}$ The fifth and fourieenth amendments of the U.S. Constitution and the early constitutions of the states manifest an approach that regards property rights as fundamental personal rights. Dietze argues that in light of Locke's writings the phrase "pursuit of happiness" in the Declaration of Independence should be interpreted as tantamount to property rights. G. Dietze, In Defense of Property 31-32 (1963). Mr. Justice Story observed in 1829

[t]hat government can scarcely be deemed to be free, where the rights of property are 
of ownership rights and the relative importance of those rights, as compared with other social objectives, has changed over time. For example, Robert McCloskey argued that towards the end of the nineteenth century preservation of economic freedom and thus of private property rights was the dominant concern, although, in the past, it had been given much less weight. ${ }^{104}$ Today, these rights seem to have once again diminished in importance. Yet the proposition that through the concept of property some liberties are protected from government intervention remains a fundamental tenet of jurisprudential thinking in the United States.

It may be argued that certain liberties are safeguarded, not only by prohibiting government interference with property rights (subject to a justified "taking" with just compensation) but also by insulating the individual from certain effects of the marketplace, giving him a certain freedom from transaction. Underlying this argument is the assumption that there are some absolute property rights that must not be infringed upon by any force-public or private. Yet in developing the content of these various restrictions, different thinkers would employ varying standards depending on the source of the interference in question. Thus, those who regard economic freedom as the primary goal would largely oppose government intervention and would disapprove of protecting anyone from the consequences of property transactions. On the other hand, if regulatory restrictions are seen as essentially distributional decisions aimed at enhancing the power of the underprivileged, then, ${ }^{105}$ on the private law side, certain uncurtailable property privileges

left solely dependent upon the will of a legislative body, without any restraint. The fundamental maxims of a free government seem to require that the rights of personal liberty and private property should be held sacred.

Wilkinson v. Leland, 27 U.S. (2 Pet.) 627,657 (1829). Absolutist formulations of property rights, such as John Adams's notorious statement that

[p]roperty is surely a right of mankind as really as liberty. . . The moment the idea is admitted that property is not as sacred as the laws of God, and that there is not a force of law and public justice to protect it, anarchy and tyranny commence.

Adams, Defense of the Constitution of Government of the United States of America, in 6 Works OF JoHN ADAMS 8-9 (C. Adams ed. 1851) were given ideological base and reinforced in the "Gilded Age"; see R. McCloskey, American Conservatism in the Age of Enterprise (1951). Modern advocates constantly emphasize the relationship between freedom and protected private property rights. See G. DiETze, supra at 40-64; M. Friedman, Capitalism and FREEDOM 7-18 (1962); W. LippMan, The METHOd OF FrEedoM 100-02 (1934); Pound, supra note 101. Indeed, the problem is not to demonstrate how prevalent in American tradition the idea that property secures liberty is but rather to describe the limitations of that important objective when balanced against other social values.

104 R. MCCLOSKEy, supra note 103, at 1-21.

105 Samuels, Welfare Economics, Power, and Property, in Perspectives on Property 61 (G. Wunderlick \& W. Gibson eds. 1972). 
would be given preponderant weight over transaction powers.

The common law has rarely imposed serious restraints on voluntary arrangements between competent adults. This freedom of transaction has traditionally been most closely associated with contract law. Property law, while allowing a large measure of freedom to transact, also provides a certain degree of freedom from transaction by limiting the ways in which a seller may encumber the property he is conveying away. The endurance of rights in rem and the difficulty in reaching an agreement concerning the termination of encumbrances make this type of limitation essential if a seller is to be prevented from, in effect, legislating as to the behavior of all subsequent owners. Following this rationale, it could be argued that by invalidating certain "personal" servitudes the law prohibits undue invasion of the individual property owner's rights.

As noted above, the participants in residential private governments have not sought to use those organizations as vehicles for social reform. Rather, they have been interested primarily in efficiency-in getting the most services to all residents at the least cost. That purpose, which is effectuated by the use of servitudes, justifies a degree of compulsion by the majority and at the same time provides a guideline to check abuses. But efficiency is not the only interest that must be considered: the individual homeowner has an interest in protecting his liberty to act within his own home. The foregoing discussion has shown that these are precisely the interests that property law was designed to accomodate. Beginning with private law as the preferred method of regulation, we turn now to an examination of another sensitive area concerning the internal affairs of residential private governments: the relationship between the developer and the community.

\section{The Developer and the Community}

As noted above, ${ }^{106}$ it was hoped that the new towns, in which residential private governments played a key role, would be modern reincarnations of the colonial New England town. Yet during the long development period required for the construction of large residential projects (in many cases more than ten years), ${ }^{107}$ it is clear

106 See text and notes at notes $40-45$ supra.

107 According to the "declarations" of various new towns, the "development period" will stretch over several years: in Woodlands, Texas, the development period is defined as a period of twenty years; in Flower Mound, Texas, seventeen years; in Maumelle, Arkansas, twenty years; and in Soul City, North Carolina, thirty years. Total control is kept by the developer only until a substantial part of the property is sold. If the development proceeds according to the plan, the residents might therefore acquire control after the first decade. 
that neither participatory democracy nor idyllic harmony can exist. The inhabitants, drawn from many different backgrounds, often have little in common, and the developer possesses nearly absolute control over the community. ${ }^{108}$ Notwithstanding the facade of owner involvement and participation, it is rather obvious that in the communities' formative years they cannot qualify as "laboratories of democracy." 109

The covenants and bylaws of the typical homeowners' association are aimed at securing absolute control for the developer until a substantial part of the project is sold. Various private government schemes are used to achieve this purpose. The model forms, proposed by the Urban Land Institute, recommend a harsh, yet straightforward technique, suggesting that the developer be given three votes per unit, while the owners have only one vote each. ${ }^{110}$ The entrepreneur thereby enjoys a majority vote in the homeowners' association until 75 percent of the lots have been sold. ${ }^{111}$ The right to amend the articles during this development period is specifically prohibited. ${ }^{112}$ The developer's control over the private government is thus assured and undesired controversies are theoretically avoided. ${ }^{113}$

The same approach has been adopted by virtually all of the large-scale horizontal developments, although with varying degrees of liberalism and sophistication. In Reston, Virginia, for example, a system of one unit-one vote prevails and gives the developer a majority up to the day he disposes of 50 percent of his plots. Thereafter a minimum of one-third of the votes is secured to him until a given date or until 80 percent of the lots are sold, whichever is later. The developer is protected, however, by "supermajority" provisions that allow 10 percent of the votes to veto fundamental changes and require approval by seven-ninths of the entire board of directors and 50 percent of the voters to amend other clauses. Since the developer chooses the directors who serve for the first five years, and may later enlarge his voting power by adding land to the original develop-

${ }^{108}$ Because of this developer control, it has been argued that the new town resembles the model of the company town. Godschalk, New Communities or Company Towns? An Analysis of Resident Participation in New Towns, in New Towns: Why AND FOR WhOM? 198, 199 (H. Perloff \& N. Sandberg eds. 1973).

109 See Twentieth Century Fund Task Force on Governance of New Towns, New TOWNS: LABORATORIES FOR DEMOCRACY (1971).

110 The Homes Association HandBooK, supra note 10, at 386.

III Id. at 387 n.18. After 75 percent of the parcels are conveyed, the developer possesses only one vote per unit. Id.

112 Id., Article N, section 1 at 392.

113 An owners' rebellion is, of course, always a possibility. See note 119 infra. 
ment, it seems clear that he will be able to forestall any amendment of the servitudes and will enjoy "political" control over the development for as long as he deems necessary. ${ }^{114}$

Federally-sponsored new towns employ a somewhat different scheme. According to HUD's guidelines, the right to vote in the association must be granted to owners and renters alike. ${ }^{115}$ Perhaps fearful that a system that does not endorse the principle of "one man-one vote" might be held unconstitutional, ${ }^{116}$ HUD also insisted that the developer have only one vote in the private organization. This requirement does not, however, prevent the entrepreneurs from keeping control. As is often done in corporations, the device of special voting classifications is used to maintain minority control. At the outset, the developer, who is referred to as a "class B" member, has the power to choose the entire board of directors except for one, who is elected by and from the members of the association (class A). Thereafter, whenever a certain number of dwelling units are occupied, class A members gain the right to elect one more class B director. In this way the system provides for the gradual transfer of power to the residents. In several of these projects, the developer also has the right to veto any amendments to the original charter until the project is substantially completed. ${ }^{117}$ Other projects permit the modification of all the servitudes, with no power vested in the class B members to prevent it, if two-thirds of the residents and the Secretary of HUD approve. ${ }^{118}$ The entrepreneurs in these projects seem to enjoy tremendous powers, notwithstanding their negligible voting rights. The servitudes provide the associations' directors and the architectural control committees (the majority of the members of which are also appointed to a fixed term by the developer) with far-reaching discretionary powers. Furthermore, in several ventures it is provided that only the directors have the power to formulate and amend the associations' bylaws. ${ }^{119}$

II See the Bylaws and the Protective Covenants and Restrictions of Deed of Dedication (1970 ed.) for Reston, Va.

11524 C.F.R. \& 710.6(A)(3) (1975).

it Cf. Chicago Comment, supra note 3.

117 See, e.g., Article XIII, section 13.02 of the declaration of Flower Mound, Texas.

its See Article XV, section 15.01 of the declaration of Maumelle, Arkansas; Article XV, section 15.01 of the declaration of Woodlands, Texas; and Article XIII, section 13.01 of the declaration of Soul City, North Carolina.

i' See Article XIII of the Articles of Incorporation of the Maumelle Residents Association and Article $\mathrm{X}$ of its bylaws. It is possible, of course, that the residents of a developing community will find their impotence intolerable. Whatever the provisions involved, it is interesting to speculate about how HUD would respond to a "residents' rebellion" which, unlike the one that actually occurred in Reston, Virginia, was successful in severely abrogat- 
The reasons for the interest of the developer in maintaining "political" control during the development period are rather obvious. The developer's only goal is the orderly production of a commodity to be sold at a price that will yield the highest possible return on his investment. Once all the "landed stock" is disposed of, there is no reason for the developer to continue his participation in the community. Building a new town is, however, a most complex and uncertain process. During the period in which a substantial investment is at risk, a residential private government system is essential so that the developer may control the application of the assessment money and police his investment by supervising independent contractors and residents. To ensure freedom of action in using the private government for these purposes, the developer often has the plan endorsed in advance by the local county government by special legislation, the application of Planned Unit Development (PUD) concepts ${ }^{120}$ or contract zoning. Since the residents would not meet the minimum population requirements for incorporation for a long time, if ever, they would find it difficult to break the developer's legal control of the project. The residents may regard the facilities as inadequate or overcrowded and consider their investment threatened by commercial and industrial structures or high density and lower income housing. They may vehemently oppose certain standards decreed by the architectural committee or the channeling of their payments to certain projects. Above all, the residents may want the right to structure the environment in which they live and raise their children. Because of his superior legal position, however, the developer is free to ignore these desires when recognition of them would impair his profit-making potential.

It is true that the residents could threaten the developer's reputation and thereby upset sales or could use their electoral influence to encourage the local authorities to impose some restraining measures. ${ }^{121}$ But these bargaining points are outweighed by the leverage

ing the developer's powers. See Godschalk, supra note 108, at 203-07. HUD's acquiescence in such changes might relieve the developer of his multimillion dollar liabilities, and HUD would be hard-pressed not to permit the loss of the taxpayers' money used to finance the project. On the other hand, the financing agreements do not show how HUD could withhold its approval in such a case, for the provisions seem to imply that HUD is to act as a neutral umpire. By not confirming the decision, it could be alleged that HUD restricts citizen participation, contrary to its own regulations, 24 C.F.R. $\$ 710.6$ (f) (1975), and deprives the members of the community, without sufficient cause, of their property rights and freedom to govern their own affairs.

120 See, e.g., Ali Model Land Development Code $\S 2-210$ (Proposed Off. Draft 1975).

121 For a discussion of the influence of citizens groups on suburban governments see $R$. Linowes \& D. Allensworth, The Politics of LANd Use 114-42 (1973). See also Godschalk, 
a developer might possess over the local government (especially a rural one $)^{122}$ and over the members of the community. The ability to distribute favors and increase amenities could win the developer some support. A rebellion against him could prove quite costly.

Because the developer possesses a great deal of power over the residents, the problem of abuse is ever-present. Some land development corporations are subsidiaries of manufacturing firms or conglomerates that control various industries. ${ }^{123}$ The developer therefore has an incentive to attempt to force the local population to buy the products and services of the parent corporation. ${ }^{124}$ This could be done either directly in building operations or more subtly through the manipulation of architectural control standards to compel the purchase of certain building materials, fences and household equipment. Abuses may occur where private zoning schemes are established, and the developer can, in effect, grant local monopolies to certain commercial establishments. The monopoly granted the Gulf gas stations in the Reston, Virginia, project is a conspicuous example of such practices. ${ }^{125}$ In the absence of neighborhood competition, these monopolies could charge higher prices to reflect the "inconvenience costs" of commuting to and shopping at the more distant locations. The developer could also abuse his power by misapplying assessment money, channeling it to promotional activities or directing it towards the next stage of the development-even though such lands had not yet been brought into the development and might never be annexed to the existing community. The maintenance franchise in condominiums might be awarded on the basis of connections or kickbacks instead of competitive bidding or reliability.

There has been some literature on the possibility of curtailing

supra note 108 , at $303-07$, for a description of the actions taken by the residents of Reston, Virginia, to mobilize the local government's support in their dispute with the developer.

${ }_{122}$ See, e.g., the experience in Levittown, N.J., in H. GANS, supra note 36, at 16-18, 335.

123 See L. Grebler, supra note 20, (Table 1.3) at 8-9, (Table 1.5) at 14-15. For a discussion of the benefits of associated industrial activities, see id. at 53-54. Goodkin contends that many big corporations entered the real estate development business with the initial intention of expanding the market for their products. For example, Reynolds Metals and Alcoa initially regarded their residential projects as a way to promote the use of aluminum in construction. Westinghouse, it is alleged, acquired a large development company with the idea of setting up an "urban laboratory" for product and systems testing. Ogden's real estate subsidiary was likewise formed to use the parent firm's plumbing, heating and air conditioning systems in construction. See L. Goodkin, supra note 18, at 25 . As to the motives of the major utility companies in their attempts to move into the real estate industry, see id. at 22-23.

124 Cf. Landers, A Unified Approach to Parent, Subsidiary and Affliate Questions in Bankruptcy, 42 U. CHI. L. Rev. 589 (1975).

125 Chicago Comment, supra note 3 , at 395. 
the developer's domination to cure these abuses. Proponents of government intervention advocate employing social planners and establishing a "board of overseers" with the power to intervene in the affairs of the residential private government. ${ }^{26}$ Other critics argue that the internal structure of the organization should be modified. It is suggested, for example, that compelling a gradual transfer of power to the residents, as is done in federally-sponsored new communities, would suffice. ${ }^{127}$ Other commentators contend that the residents' political power should be upgraded by early incorporation and the formation of homeowners' associations independent of the developer, by the even earlier transfer of some planning responsibilities and the disclosure of all relevant economic data to the residents, and by the maintenance of continued, steady financial support for community activities. ${ }^{128}$

There are several factors that must be considered when boundaries are set and abuses defined in the context of the balance of power in residential private governments. First, it seems clear that the developer's ability to carry out his building plans, which were approved by public authorities, should not be hampered by the residents. But this conclusion does not require the total rejection of cooperation. Developers may argue that residents often fail to consider the interests of the community as a whole and tend to react in an extreme manner. Yet even if this is true, input from the residents is crucial both as an end in itself and as a means of gaining valuable knowledge about the community's needs and desires for services, facilities, and planning.

Second, the residential private government scheme must provide for a gradual transfer of power so that a vacuum is not created by the developer's departure. ${ }^{129}$ Recent research has indicated that condominium and townhouse owners who are disenchanted with the operation of their homeowners' associations generally blame the developer for such failures; his abrupt departure, without an organized transfer of responsibility and a period of training, is the reason usually given. ${ }^{130}$ The importance of having a residential private government scheme that will provide for local participation

126 See, e.g., S. ScotT, Local Government and the Large New Community (U. of Cal. Inst. of Governmental Studies, Pub. Affairs Report No. 3, 1965); Kraemer, Developing Governmental Institutions in New Communities, 1 URBAN LAW. 268 (1969).

${ }_{127}$ Mullarkey, The Evolution of a New Community: Problems of Government, 6 HaRv. J. LEGIS. 462 (1969).

123 See, e.g., Godschalk, supra note 108, at 215-19.

12 See Homes Association HANDBooK, supra note 10, $\S 15.5,-.8$, at 240-46.

130 C. Norcross, supra note 27 , at 8. 
without tying the developer's hands and will establish a method for transferring control should not be minimized; these organizational factors are no less significant than compliance with building codes or zoning restrictions on building density. Since local, municipal and county governments are already in the business of granting permits and inspecting developments, they should also be empowered to review the homeowners' association rules to insist on minimum citizen participation and a reasonable scheme for the transfer of power in developments over a certain size. It is regrettable that the proposed Model Land Development Code, which demonstrated a certain sensitivity to citizen participation in the planning process, ${ }^{131}$ ignored the present topic when considering PUDs and other special projects. ${ }^{132}$

Yet, on balance, it is highly questionable whether direct public government regulation should exceed such limited and local boundaries. Greater intervention by public officials in local affairs would increase costs and deter development by increasing bureaucratization; further, it is doubtful whether such an agency would be able to understand local sentiments and adjust competing interests equitably. In the final analysis, the introduction of public government as a referee would probably destroy, rather than promote, cooperation and harmony.

In recent years the courts have assumed a growing part of the task of resolving the disputes referred to above. Cases involving discretionary servitudes have replaced the bulk of traditional litigation regarding servitudes. In considering these cases, the judiciary has already been instrumental in laying down boundary lines and acting against certain abuses. Today, the developer's powers are checked and controlled by the courts. Still, doctrines are but slowly formulated and most of the legal remedies are as yet ad hoc solutions; the precedents therefore provide unsatisfactory guidelines for the behavior of all homeowners' associations.

\section{A Proposal for Regulating Residential Private GOVERNMENTS}

It has long been the practice of developers in this country to impose land use restrictions upon the sale of lots in their subdivisions. ${ }^{133}$ The creation of such a "general scheme" produces recipro-

131 ALI Model Land Development Code $\$ 2-307$ (Proposed Off. Draft 1975).

'32 See, e.g., id. \$ 2-210.

${ }^{133}$ The practice dates back to the first half of the nineteenth century. See Barrow v. Richard, 8 Paige 351 (N.Y. Ch. 1840). 
cal servitudes; each lot owner is under a duty to comply with the restrictions and has the right to enforce them against his neighbors. ${ }^{134}$ Although the burdens attached to different lots within the subdivision might vary, basic equality of treatment-in the sense that each owner is deemed both a promisor and a promisee-is nevertheless preserved. The sole purpose of the general scheme is to preserve the community as planned and so to secure property values and desired living conditions. Accordingly, when the general scheme no longer serves that purpose (due, for example, to a radical change in circumstances) $)^{135}$ the mutual servitudes expire.

The basic flaw in this system is its rigidity. Unless restricted by the original document or statutory limitations, ${ }^{136}$ servitudes are of perpetual duration, and, since they inure to the benefit of all owners, no modification in the plan can be made without the consent of all the lot owners. This system confronted the developer with a dilemma: he needed to have a general scheme for the community in order to attract purchasers, but without the ability to adapt the plan to changing conditions, he could easily wind up in financial ruin. To retain the benefits of the general scheme and yet achieve flexibility, developers began reserving the power to amend the restrictions.

When the courts were first confronted with these "discretionary servitudes," their reaction was to treat them as merely personal powers held for the benefit of the developer alone. ${ }^{137}$ The residents thus became subject to the developer's complete control-even when his decisions were motivated by whim or caprice. ${ }^{138}$ Such servitudes, lacking mutuality and reciprocity, negated the existence of a general scheme. ${ }^{139}$ Accordingly, it was held that no owner could enforce the restrictions, even in cases where the developer had not

${ }^{134}$ See generally Dunham, Promises Respecting the Use of Land, 8 J. Law \& Econ. 133 (1965).

I3s See generally 2 American Law of Property § 9.39, at $444-48$ (A. Casner ed. 1952).

1385 RESTATEMENT OF PROPERTY, Introductory Notes to ch. 41 at 3060-61 and to ch. 47 at 3282-83. For modern statutory provisions that limit the life span of servitudes, see $R$. KratoviL, Real Estate LaW 346 (6th ed. 1974).

${ }^{137}$ See generally Annot., 4 A.L.R.3d 570, 572-82 (1965).

${ }_{138}$ See, e.g., Le Blanc v. Palmisano, 43 So. $2 d 263$ (La. Ct. App. 1949), where the court observed that a decision concerning the construction of a tourist court was "contingent entirely upon the caprice" of the subdividing corporation. Id. at 266.

${ }_{139}$ See Gibney v. Stockdale Corp., 20 Del. Ch. 272, 174 A. 117 (1934); Le Blanc v. Palmisano, 43 So. 2d 263 (La. Ct. App. 1949); Rankin v. Brown, 142 N.J. Eq. 180, 59 A.2d 645 (1948); Bright v. Forest Hill Park Dev. Co., 133 N.J. Eq. 170, 31 A.2d 190 (1943); Brighton by the Sea, Inc. v. Rivkin, 201 App. Div. 726, 195 N.Y.S. 198 (1922); Shaddock v. Walters, 55 N.Y.S.2d 635 (Sup. Ct. 1945); Ludlum v. Haskins, 177 Misc. 103, 28 N.Y.S.2d 384 (Sup. Ct. 1941); Humphrey v. Beall, 215 N.C. 15, 200 S.E. 918 (1939). 
exercised his discretionary powers. ${ }^{140}$ This characterization of the effect of discretionary servitudes thus foreclosed the possibility of imposing judicial restraints on the developer. ${ }^{141}$

In the last two decades, however, the courts have changed their attitudes toward discretionary servitudes and have adopted a presumption that discretionary powers are intended to serve the community-not the developer. Once that premise was accepted, it followed that general schemes were not defeated by the mere reservation of powers and that the developer's decisions were made susceptible to judicial review. It should be emphasized, however, that this supervision was not aimed at stripping either the developer or the residential private government of its power but rather at eliminating clearly "unreasonable" exercises of power. Unfortunately, the courts have been slow in developing standards to guide the determination of what constitutes a "reasonable" decision. This section will suggest such standards, drawn from traditional property and trust law.

Servitudes ${ }^{142}$ in the context of residential private governments are often created by a two-step process: first the grant of power is made, and later the power is exercised. But they remain servitudes nevertheless and therefore are subject to all the legal restrictions governing the outright creation of such interests-including the "touch and concern" test. ${ }^{143}$ Thus, a burden may not be imposed unless it would improve the use and enjoyment of the land owned by the beneficiaries (the developer or the other homeowners). Under this test, a court would have to invalidate restrictions aimed at promoting ideological uniformity, providing the organization or someone else with collateral gains, or requiring participation in pol-

140 See Le Blanc v. Palmisano, 43 So. 2d 263 (La. Ct. App. 1949); Rankin v. Brown, 142 N.J. Eq. 180, 59 A.2d 645 (1948); Shaddock v. Walters, 55 N.Y.S.2d 635 (Sup. Ct. 1945); cf. Lugg v. Stirnweis, 43 N.Y.S.2d 475 (Sup. Ct. 1943).

The English courts reached the opposite result. See Elliston v. Reacher, [1908] $2 \mathrm{Ch}$. 665 , in which discretionary powers were held not to negate the general scheme. See also $\mathrm{R}$. Megarry \& H. Wade, The Law of Real Property 768 (3d ed. 1966). At least one early American decision went in the same direction. See Laverack v. Allen, 2 N.J. Misc. 637, 130 A. 615 (Ch. 1924).

"Th The burden undoubtedly had to "touch and concern" the land so that the restrictions could be applied against an assignee of the original seller. Yet the benefit, while dependent on the ownership of the developer, was nevertheless regarded as personal. Accordingly, when the entrepreneur disposed of all the property he owned in the area, he could no longer exercise his rights. See Ludlum v. Haskins, 177 Misc. 103, 28 N.Y.S.2d 384 (Sup. Ct. 1941).

142 See text and note at note 92 supra.

${ }^{143}$ For an explanation of the "touch and concern" doctrine, see U. Reichman, supra note 90, at 188-268; Berger, A Policy Analysis of Promises Respecting the Use of Land, 55 Minn. L. REv. 167 (1970); Bigelow, The Content of Covenants in Leases, 12 Mich. L. Rev. 639 (1914). 
itical activities. Similarly, a business or building permit could not be denied if the activity in question would not adversely affect neighboring lands. The same conclusion applies to other types of "licenses" that are extensively used in planned communities today, such as licenses to keep pets, conduct professional activities, install electrical equipment and the like.

Although the touch and concern doctrine thus supplies certain limitations on residential private governments' powers, in practice it would be invoked in only a few cases. A wide variety of activities clearly touch and concern adjacent lands: rules regarding the exteriors of houses, set-back lines, and the abatement of nuisances, for example, all bear on the "use and enjoyment" of the neighboring lands. Moreover, the doctrine does not apply to the termination of servitudes; thus, it could not be used to keep the developer from exempting certain property from onerous restrictions-perhaps for a price. Clearly, some further regulation is needed to curb abuses of power.

In determining what constitutes an abuse of a discretionary power the courts, unfortunately, have failed explicitly to classify the jural relations between the persons vested with the authority and those subject to it. ${ }^{144}$ However, they seem to have done so implicitly. In what follows, building permit cases, which are typical of the new judicial attitude toward discretionary servitudes, will be examined for such an implicit characterization.

In the building permit cases, it is clear that a permit system will not be invalidated even if there are no standards to guide the discretion of the architectural control board. ${ }^{145}$ Rather, controls on that discretion have been implied from the use of the building permit system as a device to implement the general scheme $e^{146}$ and hence as a measure adopted to protect the property rights of the individual

14 The reservation or grant of powers that might affect possessory estates is a rather common phenomenon in property law. Such powers include powers of termination ("right of entry"), powers of appointment and powers held by trustees. It is generally recognized that servitudes may, like estates in land, be affected by powers. See 2 AMERICAN Law OF Property, supra note 135 , at $\S 8.87$. The powers vested in the homeowners' association should be considered as a separate element in the legal structure of residential private governments. Accordingly, the grant of power is not subject to the "privity of estate" rule and the holder of the power does not have to be an owner of land in the community.

145 Annot., 40 A.L.R.3d 864, 874-76 (1971).

146 "[The power to approve building plans] was intended to provide machinery in the aid of the enforcement of the covenants rather than to provide a means by which the common plans could be weakened by modification." Snashall v. Jewell, 228 Ore. 130, 137-38, 363 P.2d 566, 570 (1961). See also La Vielle v. Seay, 412 S.W.2d 587 (Ky. 1966); Kirkley v. Seipelt, 212 Md. 127, 128 A.2d 430 (1957); Ardmore Ass'n v. Bankle, 329 Mich. 573, 46 N.W.2d 378 (1951); Emma v. Silvestri, 101 R.I. 749, 227 A.2d 480 (1967). 
lot owners..$^{147}$ The courts have thus, time and again, declared that the boards cannot subject purchasers to their personal tastes and aesthetic preferences. Proposed structures may not be rejected simply because the developer or a nominated committee happen to dislike them. ${ }^{148}$ To decide whether the restrictions involved were permissible, the courts have usually looked first to the general plan of the development: the developer's authority is measured by the community plan and cannot be used in violation of the explicit or implicit terms of the servitudes. Thus a prohibited land use may not be authorized, and a permitted use may not be barred. ${ }^{149}$ The courts have also looked at the building patterns already established in the community; ${ }^{150}$ these patterns are viewed as a collaborative effort on the part of the purchasers and the developers and thus as an elaboration on the general plan. Beyond conformity to the plan, both as written and de facto, however, the only requirement for the exercise of power is that of "reasonableness," which is seen as a reasonable relation between the intended function of serving the community and the actual application of the authority.

The basic rule consistently followed by the courts in the building permit cases is that discretionary powers have to be exercised equitably for the benefit of the lot owners in the community. Whenever the developer fails to live up to that duty, by imposing overly severe restrictions on the petitioning lot owner, ${ }^{151}$ utilizing his authority in a self-serving fashion or in undue preference to the inter-

147 See Carranor Woods Property Owners' Ass'n v. Driscoll, 106 Ohio App. 95, 153 N.E.2d 681 (1957); West Hill Colony, Inc. v. Sauerwein, 78 Ohio L. Abs. 340, 138 N.E.2d 403 (Ct. App. 1956); Exchange Realty Co. v. Bird, 16 Ohio L. Abs. 391 (Ct. App. 1933).

14s See, e.g., Donoghue v. Prynnwood Corp., 356 Mass. 703, 255 N.E.2d 326 (1970).

14 Approvals in violation of specific restrictions were set aside in Snashall v. Jewell, 228 Ore. 130, 363 P.2d 566 (1961); Johnson v. Dick, 281 S.W.2d 171 (Tex. Civ. App. 1955). For opinions holding that a use permitted by the scheme could not be disallowed, see Lushing $\mathrm{v}$. Riviera Estates Ass'n, 196 Cal. App. 2d 687, 16 Cal. Rptr. 763 (Dist. Ct. App. 1961); Voight v. Harbour Heights Improvement Ass'n, 218 So. 2d 803 (Fla. Ct. App. 1969).

150 Bramwell v. Kuhle, 183 Cal. App. 2d 767, 6 Cal. Rptr. 839 (Dist. Ct. App. 1960) (permit to erect a house that was clearly not in harmony with other structures in the development set aside); Rhue v. Cheyenne Homes, Inc., 168 Colo. 6, 449 P.2d 361 (1969) (refusal to approve the construction of a house of a completely different style than that prevailing in the development upheld even though no servitude specifically mentioned what styles were permissible); Kirkley v. Seipelt, 212 Md. 127, 128 A.2d 430 (1957) (prohibition of installing unsightly awnings affirmed for the same reason); West Hill Colony, Inc. v. Sauerwein, 78 Ohio L. Abs. 340, 138 N.E.2d 403 (Ct. App. 1956) ("mandatory" color of exterior paint to conform to the color of the exterior of houses in the community held valid). See also Winslette v. Keeler, 220 Ga. 100, 137 S.E.2d 288 (1964); Fairfax Community Ass'n v. Boughton, 70 Ohio L. Abs. 178, 127 N.E.2d 641 (C.P. Franklin County 1955).

${ }^{151}$ See, e.g., Levin v. Mountain Farms, Inc., 22 Conn. Supp. 14, 158 A.2d 493 (Super. Ct. 1959); Carroll County Dev. Corp. v. Buckworth, 234 Md. 547, 200 A.2d 145 (1964). 
ests of a certain group of owners, ${ }^{152}$ or violating the terms of the general scheme or of the developed community building standards, the decision could be set aside on an action initiated by any affected owner. ${ }^{153}$ It is clear, therefore, that reservation of such powers, at least where a building scheme is imposed, brings the person vested with that authority under fiduciary obligations. ${ }^{154}$ Although fiduciary relationships exist in various circumstances, trust law appears to be the closest analogue, ${ }^{155}$ especially when one compares the way in which courts scrutinize decisions reached in our cases and decisions made by a trustee in administering trust property. ${ }^{156}$

The developer, holding discretionary powers for the benefit of the homeowners, may be said to hold those powers in trust. ${ }^{157}$ The

152 See, e.g., Donoghue v. Prynnwood Corp., 356 Mass. 703, 255 N.E.2d 326 (1970).

${ }_{133}$ Since the discretionary powers are construed to protect the interests of the owners, each of them may challenge an unjustified decision to grant a building permit. See Bramwell v. Kuhle, 183 Cal. App. 2d 767, 6 Cal. Rptr. 839 (Dist. Ct. App. 1960); Snashall v. Jewell, 228 Ore. 130, 363 P.2d 566 (1961); Johnson v. Dick, 281 S.W.2d 171 (Tex. Civ. App. 1955).

154 In Black's Law Dictionary 753 (rev. 4th ed. 1968) a fiduciary is defined as a person "having a duty, created by his undertaking, to act primarily for another's benefit in matters connected with such undertaking." See also 1 A. ScOTT, THE LAW of TrusTs $\S 2.5$, at 39 (1967): "A fiduciary relationship involves a duty on the part of the fiduciary to act for the benefit of the other party to the relation as to matters within the scope of the relation. . . . As to matters within the scope of the relation he is under a duty not to profit at the expense of the beneficiary. If the fiduciary enters into a transaction ... [that] is unfair to the beneficiary, it can be set aside by him."

${ }_{135}$ The closest case to ours other than trust is agency. Although an agent stands in a fiduciary relationship toward his principal, the category does not quite fit the situation of the developer-homeowner relationship. First, the homeowners cannot be seen as principals since they did not grant the developer any powers (he reserved them for himself), and they are unable to deprive him of his authority. Similarly, they cannot control the actions of the developer or direct the exercise of his discretionary powers. Second, it is very doubtful that the developer could subject the owners to vicarious liability for his actions.

${ }^{135}$ See 3 A. ScoTT, supra note $154, \S 187$, at 1501 :

To the extent to which the trustee has discretion, the court will not control his exercise of it as long as he does not exceed the limits of the discretion conferred upon him. The court will not substitute its own judgment for his. . . .

In determining whether the trustee is acting within the bounds of a reasonable judgment the following circumstances may be relevant: (1) . . . the terms of the trust; (2) the existence or nonexistence . . . of an external standard by which the reasonableness of the trustee's conduct can be judged; (3) the circumstances surrounding the exercise of the power; (4) the motives of the trustee in exercising or refraining from exercising the power; (5) the existence or nonexistence of an interest in the trustee conflicting with that of the beneficiaries.

Compare the standard to be applied to the trustee to that applied by courts to a developer, Annot., 40 A.L.R.3d 874-76 (1971). Specifically, as to (1) above, consider the relationship between the explicit restrictions in the general scheme and the developer's powers. As to (2), compare the developer's obligation to conform his decisions to existing patterns in the community. See text and note at note 150 supra. As to (4), see, e.g., Donoghue v. Prynnwood Corp., 356 Mass. 703, 255 N.E.2d 326 (1970).

${ }^{137}$ Although in most situations, trustees are vested with a fee simple or possessory estate, 
fact that the developer is the settlor, trustee, and one of the beneficiaries does not upset this designation. ${ }^{158}$ The Rule Against Perpetuities also would not create any problems: the interests of the beneficiaries are vested and attached to the land at the moment the first lot is sold in the development. ${ }^{159}$ In fact the only doctrinal barrier to the use of the trust concept appears to be a problem in finding the intent to create a trust. ${ }^{160}$ In some cases the original declaration may state that powers are to be exercised for the benefit of all the owners in the community. ${ }^{161}$ In such a case it is obvious that a trust was actually intended. ${ }^{162}$ In many other cases the declaration makes it clear that a general scheme is being created, that the individual lot owners have the right to enforce the restrictions, and that the discretionary powers are intended to aid in the achievement of the plan's objectives. Since the powers are explicitly reserved to serve the community's owners and not merely the interests of the developer, a trust could easily be implied. If in the declaration the developer clearly and specifically reserves certain powers for his own benefit alone, a trust cannot arise with respect to those powers. In all other instances, however, a court should imply a trust or impose one by operation of law.

Once the developer or homeowners' association is found to hold powers in trust, a number of consequences follow. First, the trustee is subject to a number of duties: the duty of impartiality, ${ }^{163}$ the duty of loyalty ${ }^{164}$ and the duty of reasonable care. ${ }^{165}$ In addition, the trustee may also be required to furnish material information to the homeowners. ${ }^{168}$ Second, the developer could be compelled to per-

it is well recognized that powers may likewise be held in trust. See $1 \mathrm{~A}$. ScoTr, supra note $154, \S 88$, at 752 .

iss Id. $\S 100$, at 818 .

150 Subsequent owners are not original "beneficiaries" but "beneficiaries" by assignment. For this reason, there is no problem relating to "remoteness of vesting." Similar reasoning is applied to reject any contention that servitudes violate the Rule Against Perpetuities. The mere fact that the powers could be exercised for a long period of time likewise does not constitute a violation of the rule. See 6 American LAW of PrOPERTY, supra note 135, \$24.63, at 158 .

t6 See 1 A. Scotr, supra note $154, \S 24$, at 192-96.

'II Such clauses are usually found in developments where a homeowners' association is initially established.

$1121 \mathrm{~A}$. ScoTT, supra note 154, \& 24, at 192-93: "Where the owner of property transfers it to another with a direction . . . to hold or deal with it for the benefit of a third person, this may be a sufficient manifestation of an intention to create a trust. So also where the owner of the property declares that he holds it for the benefit of another . . . ." (footnote omitted).

113 Cf. I Restatement (Second) of Trust \& 183, at 393-94 (1959).

164 Id. $\$ 170$, at $364-73$.

${ }^{185}$ Id. $\S 174$, at $379-80$.

II Id. $\$ 173$, at $378-79$. 
form his duties and, for a "breach of trust" (for example, selling business permits), he could not only be stripped of his powers, but could, in certain circumstances, be held personally liable as well. Several building permit decisions imposed on architectural committees standards of conduct similar to those imposed on trustees without, however, mentioning the trust analogy. ${ }^{167}$

The trust analysis, unlike the application of public law, provides the developer with the freedom to mold the legal structure of the residential private government as he sees fit. Thus, the most important restraints on his activities are not legal but are restrictions imposed by the market mechanism. If he explicitly reserves powers for his sole benefit, the trust analysis would be inapplicable. Because of the possible dampening effect on sales, it is unlikely that many such straightforward declarations would be made. Currently, developers often hide their real motives behind the veil of the homeowners' association, which they control during the development period, or simply reserve unqualified discretion. Under the proposed rule, such practices would be wholly ineffective. If the developer wanted to preserve self-serving powers, he would have to say so openly or else the reserved powers would have to be used solely for the benefit of the community and the homeowners.

Decisions in other areas besides building permit cases demonstrate that the trust analysis could be useful in regulating many aspects of the residential private government's operations. In this brief survey I will mention a few of the more interesting questions.

Perhaps the most troublesome question relates to the "legislative" process of amending and terminating existing servitudes. The entity vested with such authority is expected to use it in an impartial and nonarbitrary manner. Usually, a probable contribution to the community's welfare suffices to uphold the measure. But where the interests of the decisionmaker conflict with those of the owners, a closer scrutiny is required. ${ }^{168}$ Developers' decisions in this area should, therefore, be subjected to a rigorous examination by the courts. ${ }^{169}$ Second, even if the decisionmaker's motives are not open to question, modifications in the servitudes must apply

${ }^{167}$ For an obligation to provide reasons for refusing to grant a permit (which correspond with a trustee's duty to furnish information), see Syrian Antiochian Orthodox Archdiocese v. Palisades Associates, 110 N.J. Super. 34, 264 A.2d 257 (Super. Ct. Ch. 1970). For the duty to exercise reasonable care before granting a permit, see Bramwell v. Kuhle, $183 \mathrm{Cal}$. App. 2d 767, 6 Cal. Rptr. 839 (Dist. Ct. App. 1960). As to "reasonableness" of decisions, see Annot., 40 A.L.R.3d 864, 874-76 (1971).

${ }^{168}$ Cf. 3 A. ScoTT, supra note $154, \S 187.5$, at 1524.

189 Cf. Flamingo Ranch Estates, Inc. v. Sunshine Ranches Homeowners, Inc., 303 So. 2d 665 (Fla. Dist. Ct. App. 1974). 
equally to all similarly situated members of the community (unless, of course, "spot modifications" are authorized in the declaration). ${ }^{170}$ This duty of equality of treatment would, for example, be violated when the "legislative" powers are manipulated to allow the establishment of churches serving only one particular denomination or religion. ${ }^{171}$ Changes in the system of computing the assessments would be invalidated (even where an amendment of that sort is permitted by the "general scheme") when disproportionate financial liabilities were imposed on a minority. Similar considerations should guide judicial review of the residential private government's administrative process. Thus, the association's income could not be used for purposes unrelated to the community's welfare ${ }^{172}$ or to provide services in a discriminatory fashion. ${ }^{173}$ Property held by the association for the use of the residents usually could not be transferred ${ }^{174}$ or operated so as to allow access to only a few owners. Criteria employed in the building permit cases should govern other licensing instances as well. ${ }^{175}$

Condominiums differ from horizontal developments with homeowners' associations in several respects, ${ }^{176}$ but they face the same problems as indicated in this section. ${ }^{177}$ Although it is ques-

170 Riley v. Boyle, 6 Ariz. App. 523, 434 P.2d 525 (1967); Cowherd Dev. Co. v. Littick, 361 Mo. 1001, 238 S.W.2d 346 (1951); Lakeshore Estates Recreational Area, Inc. v. Turner, 481 S.W.2d 572 (Mo. Ct. App. 1972); Montoya v. Barreras, 81 N.M. 749, 473 P.2d 363 (1970); Zent v. Murrow, 476 S.W.2d 875 (Tex. Civ. App. 1972).

171 See West Hill Baptist Church v. Abbate, 24 Ohio Misc. 66, 261 N.E.2d 196 (C.P. Summit County 1969). This case was resolved by applying the first amendment; the reasoning therefore contradicts a line of decisions reached in other jurisdictions (see note 180 infra), but the result is, nevertheless, justified if the trust analysis is followed.

${ }^{172}$ Cf. Japanese Gardens Mobile Estates, Inc. v. Hunt, 261 So. 2d 193, 195 (Fla. Dist. Ct. App. 1972).

173 Such an allegation has been raised, but not substantiated factually. See Metryclub Gardens Ass'n v. Council, 36 So. $2 d 56$ (La. Ct. App. 1948); Lake Dev. Enterprises v. Kojetinsky, 410 S.W.2d 361 (Mo. Ct. App. 1966). In Fox Lake Hills Property Owners Ass'n v. Fox Lake Hills, Inc., 120 Ill. App. 2d 139, 256 N.E.2d 496 (1970), the court made it rather clear (in dicta) that discrimination in spending could be prohibited.

${ }^{174}$ Peterson v. Greenway Parks Home Owners Ass'n, 408 S.W.2d 261 (Tex. Civ. App. 1966). Property designated under a general scheme for the use of the residents of a certain community is usually treated as trust property even when recorded in the developer's name. Rowan's Ex'rs v. Town of Portland, $47 \mathrm{Ky}$. (8 B. Monr.) 232 (1848). The same applies to homeowners' associations. Peterson v. Greenway Parks Home Owners Ass'n, 408 S.W.2d 261 (Tex. Civ. App. 1966).

175 In Edgemoor Terrace Civic Ass'n v. Spinning Wheel Inn, Inc., 256 A.2d 284 (Del. Ch. 1969), an "administrative" decision regarding a private business license was reviewed in a way similar to that employed in the building permit cases.

${ }_{176}$ See generally Berger \& Rohan, Condominium versus Home Owner Associations Arrangements-An Overview, in Symposium on the Law of Condominiums, 48 St. JoHN's L. REv. 736 (1974).

177 See Note, Promulgation and Enforcement of House Rules, 48 ST. JoHN's L. REv. 1132 (1974). 
tionable whether the "touch and concern" rule could be applied to condominiums, ${ }^{178}$ the trust analysis seems to be relevant.

A brief survey of the cases indicates that a new body of law is emerging. In recent years the reality of life under residential private governments has triggered a great deal of litigation. While the propositions advanced in this paper are not entirely supported by the decisions, they are in accord with the general trend of the law. It has become evident that any form of government, even a private one, is prone to mistakes and may abuse its power. The judiciary has rightfully refused to adopt a "hands-off" policy in the field of residential private governments, but has refused also to take the easy way out by applying public law standards. While a clear set of rules has yet to emerge from the decisions, the trend toward using property concepts appears clear, and experience has brought us to the point where it is possible to point out some possible approaches.

These approaches are relatively simple. First, the court should inquire whether the restriction in question "touches and concerns" neighboring lands; if so, the question then is whether the "trustee" acted properly in imposing the restriction (or granting the permit, license, etc.). Did he act in accordance with the "declaration" (in effect, the trust instrument)? If so, did he act impartially, consistently, and with an eye toward the welfare of the community alone? If so, the restriction is a valid one, and the court need not inquire any further.

Again, these standards are not meant to cover completely the subject of residential private governments. They are only a starting point to be used as the residential private government movement grows and develops; case-by-case determination will be necessary to give content to these standards that, in this context, are somewhat vague, but are, nevertheless, the well-known standards of private law that have been developed and used by the common law for many years.

\section{Residential Private Governments and the Public INTEREST}

Residential private governments, at least in the context of new town developments, have largely failed as vehicles for social reform. In fact, it may be argued that such organizations aggravate the

${ }^{178}$ The regulatory system in condominiums is based on statutory law, which generally does not show much awareness of the problems mentioned in this paper. While servitudes are explicitly used in condominiums, it is not clear whether the association's rules could be conceptualized as such, for they are based on the local "enabling" legislation. 
problems they were intended to help resolve by closing off the community, through both the exclusionary use of servitudes and the denial of membership rights to various inhabitants of the community, such as lessees. In my view, these fears are as exaggerated as the early hopes associated with such organizations; the public interest is neither served nor substantially threatened by residential private governments. Yet it is this concern for protecting the public at large that may bring public law regulation to bear on the residential private government.

As argued above, homeowners' associations do not perform a public function and should not be subjected to constitutional and administrative law restraints. Unless a clear and convincing case is made that the residential private government infringes the constitutional rights of nonowners and that such a violation is so injurious as to outweigh the constitutionally protected rights of free association $^{179}$ and property privileges of the homeowners, the public law route should not be considered. To date no such convincing case has been presented, and the courts have so far refused to apply constitutional rules to homeowners' associations. ${ }^{180}$ Nevertheless, several law review comments have argued that the residential private government structure should be regulated in a way that would reduce the binding force of the community's general scheme and modify its voting system. It is submitted that in these two instances, as well as in other cases, it is unwise and unnecessary to go beyond the regulation provided by state law.

\section{A. Guarding Against the Exclusionary Use of Residential Private Government Servitudes}

The fact that zoning ordinances are often manipulated to exclude low-income classes from residing in (mainly) suburban areas has prompted the recent development of the "exclusionary zoning doctrine." Based on several different constitutional theories, ${ }^{181}$ this doctrine has been used in several jurisdictions ${ }^{182}$ to invalidate such practices. Several commentators have argued that servitudes should

13 See, e.g., Justice Douglas's remarks in Moose Lodge No. 107 v. Irvis, 407 U.S. 163, 179.80 (1972) (Douglas, J., dissenting).

1 Fo For a line of cases rejecting the argument that covenants excluding churches from a community are unconstitutional, see Annot., 13 A.L.R.2d 1239 (1950). For the rejection of the idea that the principles of exclusionary zoning should be applied to general schemes, see note 193 infra. See also note 83 supra; Syrian Antiochian Orthodox Archdiocese v. Palisades Associates, 110 N.J. Super. 34, 40, 264 A.2d 257, 261 (Super. Ct. Ch. 1970).

I\$1 For a summary of these theories, see R. Babcock \& F. Bosselman, Exclusionary ZoNing 32-44 (1973).

182 See generally Annot., 48 A.L.R.3d 1210 (1973). 
be subjected to the same standard of judicial review. ${ }^{183}$ On the face of it such an analogy appears logical. Like zoning, private restrictions often have an impact extending beyond those in privity of contract, and in many cases they are similar in nature to the provisions of zoning ordinances regarded as exclusionary. ${ }^{184}$ Moreover, residential private governments, like their municipal counterparts, maintain a wide range of discretionary powers as well as the ability to pass local "legislation" to pursue discriminatory policies. Yet Siegan, the most ardent proponent of the elimination of zoning, argued against such an approach. ${ }^{185}$ In his view servitudes have far less exclusionary potential than zoning since "[r]estraints created for economic considerations necessarily operate unlike those where political considerations are dominant." ${ }^{180}$ In other words, while zoning limits freedom of contract, servitudes are an expression of it. Thus, if it is assumed that developers and buyers act as rational economic men, the use of servitudes will lead to efficient use of the land, while exclusionary zoning may well hamper that efficiency.

The basic inequity that exclusionary zoning has created is the almost total ban on lower-income housing in certain localities. This result is achieved mainly by restricting large tracts of unimproved land to low-density uses only. A political decision thus prevents the free play of market forces. While courts cannot compel political entities to take affirmative action to improve the lot of the less affluent segments of the population, the exclusionary zoning doctrine may prevent the use of governmental prerogatives to deny those people the chance of bettering their living conditions. ${ }^{187}$ Yet there is no reason to apply this doctrine to servitudes in general. The communities that are privately restricted are generally relatively small, and their exclusionary powers end at the subdivision boundary lines. Accordingly, only a limited percentage of any given incorporated area is affected by servitude regulation. Private restrictions, therefore, cannot seriously impede the building of high-density, lowcost housing.

Most servitude schemes are imposed by developers and reflect their estimation concerning market demands. Although small sub-

10 Note, Exclusionary Zoning and Equal Protection, 84 Harv. L. Rev. 1645, 1668-69 (1971); Note, Snob Zoning: Must a Man's Home Be a Castle? 69 Mrch. L. Rev. 339, 359-60 n.110 (1970).

${ }^{134}$ Compare the examples at notes $19-21$ supra, with R. BaBcock \& F. Bosselman, supra note 181 , at $7-14$.

185 B. Siggan, Land Use Without Zoning 77-84 (1972).

188 Id. at 77.

${ }^{187}$ Cf. Note, Exclusionary Zoning and Equal Protection, supra note 183, at 1661. 
divisions might well be exclusionary, larger projects tend to be inclusionary since a more diversified housing mix often produces higher revenues. Large-scale developments would therefore be unlikely to produce extensive segregation. Moreover, the entrepreneur maintains substantial control until the development is complete, allowing him to respond to market fluctuations. If a demand for less expensive housing arises, the developer could plan and restrict the remainder of his property in a different fashion. The difference between decision making motivated by political, as opposed to economic, considerations may be illustrated by the conflicts generated in several larger projects by the developer's decision to build apartment houses after the sale of single family homes. Such decisions are usually confronted with bitter, but mostly unsuccessful resistance by the existing residents.

Indeed, it is unlikely that the "politically" oriented residents would ever be able to control the servitudes mechanism. Only rarely do homeowners (especially of vacant tracts) voluntarily organize to subject their property to restrictive schemes. ${ }^{188}$ Legal obstacles, such as the privity of estate requirement, contrary economic incentives, cumbersome transaction costs and the ability of a few uncooperative owners to defeat the purpose of the plan all make homeowner manipulation of servitudes virtually impossible. Since control of the servitudes will probably remain with the economically-motivated developer, it is unnecessary to invalidate the restrictive covenants, as exclusionary zoning is struck down, ${ }^{189}$ to cure the problems of suburban isolationism. ${ }^{100}$

In practice, therefore, the question narrows down to the legitimacy of private exclusionary practices in relatively small developments. The system of mutual curtailment of property rights is clearly an efficient device to enhance the desirability of the residential environment. ${ }^{191}$ Yet the more attractive the community is made, the higher the prices will be, and those in the lower end of the economic spectrum will be excluded. Those who, under the guise of applying constitutional principles, ${ }^{192}$ urge judicial intervention to

iss B. SiEgAn, supra note 185, at 79. See also Ellickson, Alternatives to Zoning: Covenants, Nuisance Rules, and Fines as Land Use Controls, 40 U. CHI. L. REv. 681, 718 (1973).

19 Note, Snob Zoning: Must a Man's Home Be a Castle? supra note 183.

10 The role of the courts in supervising the use of servitudes should not be ignored. The imposition of restrictions (under the touch and concern doctrine) and the continuation of their binding force (under the "change in circumstances" rule) are both controlled by the judiciary in a fashion that contributes to the equitable functioning of the servitude.

in Ellickson, supra note 188, at 713-14.

12 Cf. B. Siegan, supra note 185, at 82; Bigham \& Bostick, Exclusionary Zoning Practices: An Examination of the Current Controversy, 25 VAND. L. Rev. 1111, 1145-48 (1972). 
prevent such a result must realize that not only servitudes, but also any other devices for accomplishing the same objective (such as vesting title in the homeowners' association and leasing lots for long periods of time at nominal rents) would have to be invalidated. Following that route would necessarily mean the abrogation of many property rights and curtailment of freedom of choice. Thus, although the use of restrictive covenants does not cause substantial exclusion, the elimination of those covenants would necessitate a change in basic notions of American property law. It is not surprising, therefore, that even those courts that led the way in striking down exclusionary zoning regulations draw the line where servitudes are concerned. ${ }^{193}$ While some further movement towards mandated economic egalitarianism may well be desirable, commentators who seek to impose public law restrictions by blurring the distinctions between public and private institutions should address this issue directly.

\section{B. Voting Rights in Private Residential Government Communities}

It has been argued that the fourteenth amendment requires the abolition of the one unit-one vote system that prevails in residential private governments ${ }^{184}$ - at least in large-scale developments ${ }^{195}$ after the development period has ended. ${ }^{196}$ The rationale for dispensing with ownership requirements in this manner is to enable all residents to "make decisions which affect the welfare of community and nation." 197 But this goal would seem to be satisfied by the incorporation of the community ${ }^{198}$ which, after its completion, could include thousands of people. The establishment of a public entity would dispense with the justification for applying the constitutional test to the residential private government-even though the birth of a municipality does not terminate the homeowners' association. Thus, the application of the fourteenth amendment standard would

${ }^{193}$ See National Land \& Inv. Co. v. Kohn, 419 Pa. 504, 533, 215 A.2d 597, 612 (1965). This is not to say, however, that servitudes should not be invalidated when they are found to be in violation of some overriding public interest.

196 For the unconstitutionality of ownership qualifications placed upon voting rights in the "public sector," see Chicago Comment, supra note 3, at 398-402.

${ }_{105} I d$. The theory advanced in that comment is based on functional similarity between municipal corporations and the new towns' private governments. Id. at 402, 404-10. Size seems to be regarded as a relevant factor.

196 Id. at 411.

${ }^{177}$ Id. at 408, quoting Marsh v. Alabama, 326 U.S. 501, 508 (1946).

${ }^{198}$ In some jurisdictions even the incorporation of large communities is not permitted under certain circumstances. See id. at 384, n.32, referring to VA. CoDE ANN. § 15.1-785 (1974). In such cases, however, the county government enjoys the whole range of powers that urban municipalities possess. 
depend not on the nature of the organization in question, but on the existence of local public governments. Accordingly, it could be argued that it is sufficient that the residents' political rights are provided for on the county level. If not, ${ }^{199}$ is the existence of a homeowners' association a sufficient cause to increase political voting rights? And if the proposal for incorporation were defeated, would not granting political voting rights to the residents negate that decision by introducing municipal entity concepts through the back door?

At the most, votes in a political election can influence the exercise of the powers to which the political entity is legally entitled. The homeowners' association has different powers than a municipality since it derives its prerogatives from a different source-mutual limitations of property rights. Requiring popular elections in the homeowners' association as a matter of constitutional law would thus enlarge the scope of political rights granted the voters, since the residents would have a say in matters beyond the ambit of typical municipal police power. Thus, the newly enfranchised voters could, for example, influence the outcome of a vote to suspend the right of an owner to use certain facilities for alleged violation of the association's norms.

More importantly, if the private features of the association are to be maintained and the organization is to be treated as a municipality only for certain purposes, how are the boundaries of its power to be determined?"200 Are only a few "constitutional restrictions" to be imposed or do we also have to admit that certain other "municipal powers" would be vested in the private institution? If the association is assimilated to a governmental entity, it could be argued that free access to all the organization's facilities is required. ${ }^{201}$ To

in The powers of county governments vary from jurisdiction to jurisdiction and in some areas they are quite limited. Modern legislative trends are directed, however, towards enlargement of the counties' functions. See generally Advisory CoMmission ON INTERgovernmental Relations, Profile of County Government (1971).

200 Chicago Comment, supra note 3 , at 410 .

201 As a general rule, municipal corporations are not permitted to exclude any person from using the public recreational facilities. 64 C.J.S. Municipal Corporations $\$ 1818$ (1950). Extensively high user fees might justify an allegation of class discrimination. In some situations an ordinance that sanctions the exclusion of nonresidents might be upheld. See, e.g., McClain v. City of South Pasadena, 155 Cal. App. 2d 423, 318 P.2d 199 (1957). But the question of defining who is a resident of the new town for the purposes of the constitutional standard could not be easily resolved. Since we are concerned with political rights, it is questionable whether the development's plotted boundaries would qualify. If the right to vote is given to a person who does not pay "private taxes," why should it be withheld from a person who lives on the border of the new town? On the other hand, if such a neighbor could not be excluded, the purchasers of homes within the new community would be required to carry the initial cost of building the facilities for the benefit of adjacent residents. 
meet the increase in operating costs, would the association be permitted to issue municipal bonds? Would it qualify for government aid that is now provided exclusively to public entities? Left in limbo between public and private law, the residential private government would pose difficult legal questions. The ensuing uncertainties would be likely to trigger litigation and reduce the usefulness of an important device in the field of private planning. The costs might even spill over to the public domain. To dispel confusion, government agencies and regulations might be instituted. Such a tendency is clear even in a comment advocating public law enforcement which called for the establishment of an administrative agency to monitor the "development period." 202

Since the homeowners' association is founded on restrictions of property rights, the benefits received by, and burdens imposed on, the residents concern only the residents. ${ }^{203}$ And, even so far as the residents are concerned, the association's authority generally extends only to property-related matters. Those who are not willing to draw the line between public and private institutions might find it difficult to prevent the powers of the residential private government from growing to include nonowners and nonproperty concerns, a task for which it is clearly unsuited.

The residential private government's main function of regulating essentially private matters would only be distorted by the introduction of public law restraints. Therefore, unless and until the need for such public law regulation is clearly demonstrated, the power of the homeowners' association to control property-related matters in planned communities should be restrained only by the body of law responsible for its creation-private law.

\footnotetext{
${ }^{202}$ Chicago Comment, supra note 3 , at 411 .

${ }^{203}$ Theoretically, there is no problem in providing voting rights to people other than the "subjected" landowners. The practice of granting the right to vote to all residents was adopted in the federally-assisted new communities. See text and notes at note 116 supra. Landowners have, of course, much more at stake than nonowners. They could be compelled to live up to the imposed obligations (whereas others could terminate their membership and escape any liability without leaving the community), and their property values might be affected by the association's resolutions. The tendency to exclude the nonowners is therefore likely to prevail.
} 